\title{
EL TIFO EN LA CIUDAD DE MÉXICO \\ EN TIEMPOS DE LA REVOLUCIÓN MEXICANA, 1913-1916
}

\author{
América Molina del Villar ${ }^{1}$ \\ Centro de Investigaciones y Estudios Superiores \\ en Antropología Social
}

\section{INTRODUCCIÓN}

\begin{abstract}
A fines de 1910 Porfirio Díaz fue derrotado militarmente y A un año después Francisco I. Madero ganó la presidencia de la República mexicana. En febrero de 1913 el gobierno de Madero concluyó de manera violenta como consecuencia del golpe de estado de Victoriano Huerta. El gobierno de este último también fue breve y finalmente fue derrotado en julio de 1914 por Venustiano Carranza. La inestabilidad
\end{abstract}

Fecha de recepción: 9 de abril de 2014

Fecha de aceptación: 19 de junio de 2014

\footnotetext{
${ }^{1}$ Agradezco a los dictaminadores anónimos las observaciones y comentarios a este trabajo. Sin duda, permitieron precisar, afinar y desarrollar diversos aspectos no considerados en la primera versión. Gretel Ramos Bautista fue un apoyo fundamental en la captura del material estadístico. Su colaboración fue posible gracias al financiamiento que obtuve del Conacyt a mi proyecto de investigación "Las epidemias y pandemias en México, siglos XVIII-Xx (127712)”.
} 
política se caracterizó por enfrentamientos militares en la capital y en distintas partes del país, en particular en el norte y Morelos. La caída de Huerta marcó una nueva etapa en la revolución mexicana, que se tradujo en un recrudecimiento de la guerra civil. ${ }^{2}$ En este trabajo nos adentramos en las condiciones de vida y de salud de los habitantes de la ciudad de México en este contexto de incertidumbre social y política. Nuestro interés se centra en el impacto de la epidemia de tifo de 1915 y 1916 y la respuesta de las autoridades de gobierno para hacerle frente. La aparición de esta epidemia ocurrió después de enfrentamientos militares entre villistas, carrancistas, zapatistas y fuerzas federales para tomar las riendas del país. En esta contienda la toma militar de la capital era un objetivo principal. Es un momento en el cual se percibe una segunda fase del movimiento revolucionario con cruentas batallas, y un flujo de tropas y personas que huían de las zonas en conflicto. ${ }^{3}$ La guerra civil afectó la vida cotidiana de los capitalinos y, sin duda, fue la responsable directa e indirecta de la presencia de epidemias, enfermedades y hambre entre los pobladores de la ciudad de México. ${ }^{4}$

Durante el lapso de 1913 a 1916 los habitantes de la capital vivieron un ambiente de caos y de una endeble funcionalidad del Estado mexicano como consecuencia de sublevaciones

${ }^{2}$ Véase UlloA, "La lucha armada", pp. 759-793; Garciadiego, "La Revolución”, pp. 225-236; KNIGHT, La Revolución Mexicana, vol. II.

3 En los documentos emanados de la revolución mexicana, la ocupación de la ciudad de México había sido contemplada como una alta prioridad. Sobre la situación política y social de la capital entre 1911 y 1922, véase ROdríguez KurI, Historia del desasosiego, pp. 99-174.

4 Márquez Morfín y Molina del Villar, “El otoño de 1918”, pp. 121-144. 
e insurrecciones militares. ${ }^{5} \mathrm{Al}$ respecto, Ana María Carrillo menciona que ante este crítico panorama se descuidaron las medidas de higiene y de atención a la salud. ${ }^{6}$ En un estudio anterior mostramos que a partir de 1911 las condiciones sanitarias empeoraron en la capital del país. Esto se tradujo en un incremento de enfermedades infecciosas, como el tifo, la viruela y la escarlatina. El organismo encargado de hacer frente a estos problemas era el Consejo Superior de Salubridad, el cual dependía de la Secretaría de Gobernación y estaba integrado por sólo seis miembros y cerca de 2000 empleados, especialistas en diferentes ramos. Desde 1887 y hasta el golpe de estado de Victoriano Huerta, el Consejo Superior de Salubridad estuvo a cargo del doctor Eduardo Liceaga. Cabe señalar que durante estos años de incertidumbre política algunos funcionarios del antiguo régimen porfirista se mantuvieron en sus puestos, como fue el caso de Liceaga, hombre ilustre y de gran experiencia en temas de virología y salud. Si bien entre 1913 y 1916 no advertimos grandes cambios en cuanto a las atribuciones del Consejo en materia de control y prevención de epidemias, consideramos que la inestabilidad política influyó en la falta de presupuesto para atender obras públicas, como el drenaje, la limpieza y la sanidad. La insalubridad deterioró las condiciones de salud de los capitalinos. ${ }^{7}$ Aunado a lo anterior, en 1914 estalló la guerra civil. El hambre, la movilización de tropas y la crisis en los servicios sanitarios propiciaron la aparición y virulencia de diversas epidemias, como fue el tifo de 1915 y 1916 que afectó y se llevó a la tumba a centenares de capitalinos.

\footnotetext{
${ }^{5}$ Rodríguez Kuri, Historia del desasosiego, p. 91.

6 Carrillo, "Surgimiento", p. 25.

7 Molina del Villar, "De la incertidumbre”, pp. 127-137.
} 
Este trabajo persigue los siguientes objetivos. En el texto analizamos y confrontamos algunas estadísticas del impacto del tifo en las cifras de morbilidad y mortalidad de la población capitalina. Nos interesa presentar un primer acercamiento a los grupos de edad afectados y sus condiciones de vida. Para ello incluimos un apartado previo en el que mostramos la etiología del tifo y los principales factores de su diseminación. Un elemento central que debemos considerar en su origen y gravedad es el hambre y desabasto de alimentos en 1914 y 1915 . Si bien en este trabajo no nos adentramos en estos años de escasez, consideramos que este episodio contribuyó a debilitar las defensas inmunológicas de la población y fue un indicador definitivo de la pobreza prevaleciente. ${ }^{8}$ El otro tema que se busca abordar son las condiciones de insalubridad prevalecientes en algunos barrios y colonias citadinas, en donde se presentaron casos virulentos de la enfermedad. Por último, analizamos la campaña sanitaria, la cual en un momento de guerra fue un medio eficaz de control de la población y de elogiar la labor y el desempeño político del gobierno carrancista. En esta circunstancia de crisis política y ante el azote de una epidemia, el estudio de la coyuntura de 1915-1916 en la ciudad de México puede compararse al análisis de Ana María Carrillo sobre la peste de 1902-1903 en Mazatlán, en el cual la autora hace referencia a una especie de modelo militar de salud públi-

8 "Los precios de los productos se incrementaron de manera acelerada. En 1915 el maíz registró un incremento de $1500 \%$, el frijol 700\% y el arroz $800 \%$. A pesar de los esfuerzos de crear comedores públicos y de la beneficencia, el hambre fue responsable de $9 \%$ del total de muertes registradas en 1915”. ORDORICA y LEZAMA, “Consecuencias demográficas”, p. 37. 
ca centralizada, reflejado en una estricta política de detección y aislamiento de enfermos, control en el desplazamiento de la población, desinfección de hogares y personas. Como ocurrió en Sinaloa, podemos pensar que la reacción oficial ante el tifo de 1915-1916 mostró en algunos momentos una violencia mayor que el propio impacto de la enfermedad. ${ }^{9}$

SOBRE LAS FUENTES Y ABORDAJE METODOLÓGICO

El trabajo se sustenta en el estudio de dos tipos de fuentes de información. Las primeras son las cuantitativas, derivadas de tres tipos de documentos, cuyo análisis tiene que considerar los siguientes aspectos. Un problema derivado de la guerra y de los conflictos armados fue la interrupción y poca confiabilidad de las estadísticas demográficas, en virtud de que los censos y conteos de población dejaron de llevarse a cabo en este periodo de gran inestabilidad política y social. Lo mismo ocurrió con las estadísticas de salud, pues con los cambios de gobierno en la ciudad de México, se dejaron de publicar los reportes semanales y mensuales de distintos padecimientos. Este problema ha impedido a los demógrafos poder cuantificar y comparar las pérdidas de vidas provocadas por las enfermedades y por la guerra, tema que sin duda es de gran interés para los estudiosos de la revolución mexicana. ${ }^{10}$

9 A fines del siglo xix, en el combate a la peste en Europa triunfó el modelo militar de salud pública, que se exportó a otras partes del mundo, el cual podría llegar a ser más violento que la propia enfermedad. CARRILLO, “¿Estado de peste?”, pp. 1061-1062.

${ }_{10}$ De acuerdo con algunas estimaciones, de 1914 a 1918 murieron 1000000 de mexicanos, una cuarta parte en los campos de batalla y ejecutados, mientras las otras tres cuartas partes debido a la hambruna, el tifo y la 
En consecuencia y para presentar un primer acercamiento al impacto demográfico del tifo en la ciudad de México utilizamos tres tipos de documentos: 1) Las estadísticas publicadas en los Boletines del Consejo Superior de Salubridad. Su edición era mensual y publicaba, además de las cifras de morbilidad y mortalidad, informes de congresos médicos y sanitarios, así como resultados de las inspecciones sanitarias en la ciudad, la limpieza y desinfección de las casas y colonias. Los boletines eran elaborados por médicos y miembros del Consejo Superior de Salubridad. ${ }^{11}$ Cabe decir que a raíz de los conflictos armados entre 1914 y 1915, el Boletín dejó de publicarse, hecho que impidió conocer con exactitud cómo se desarrolló la epidemia en los primeros meses: 2) En 1915, con el ascenso del general carrancista José María Rodríguez ${ }^{12}$ al frente del

influenza. A las enfermedades habrá que sumar el hambre, cuyos estragos provocaron $9 \%$ del total de muertes registradas en 1915. El hambre y las enfermedades fueron elementos significativos en la dinámica demográfica durante la revolución mexicana. MEYER, La Revolución, p. 106; ORDORICA y Lezama, "Consecuencias demográficas", p. 37.

11 Agradezco a la Biblioteca José Luis Bobadilla del Instituto Nacional de Salud Pública, en particular a Natalia López, permitirnos consultar los volúmenes del Boletín del Consejo Superior de Salubridad, ts. 1 al 12, enero a diciembre de 1916, Publicación mensual (Imprenta "El Centenario"). 12 José María Rodríguez (1870-1946) fue alumno de importantes médicos de la época, como Manuel Carmona y Valle, José María Vértiz, Eduardo Liceaga y Nicolás San Juan, entre otros. Este médico combinó sus actividades médicas con su compromiso con la Revolución, particularmente al lado de Madero y Carranza. Rodríguez se unió al gobernador de Coahuila, Venustiano Carranza, en su rebelión contra Victoriano Huerta. El 7 de marzo de 1914 fue ascendido a coronel y a partir de este momento fungió como médico personal de Venustiano Carranza, a quien acompañó en todas las campañas en Chihuahua y Sonora, hasta el triunfo de la Revolución y la llegada del ejército constitucionalista a la ciudad de México. Gudiño Cejudo, “José María Rodríguez”, pp. 559-563. 
Consejo Superior de Salubridad, se implementó una política de control social y de traslado de enfermos de tifo, viruela y otros padecimientos a los hospitales de la ciudad de México con el fin de lograr su confinamiento y así evitar la diseminación del contagio. Lo anterior derivó en la elaboración de un libro acerca del traslado de enfermos de tifo y enfermedades infecto contagiosas a los nosocomios, entre los que destacaban los hospitales General y el de Tlalpan. Esta información es muy valiosa no sólo para comparar o confrontarla con las estadísticas publicadas en los Boletines del Consejo Superior de Salubridad, sino también para identificar los barrios y colonias en donde se presentaron brotes de la epidemia citadina. La relación que se hace en el libro sobre enfermos infecto-contagiosos contiene nombre, género, domicilio, origen del reporte y nombre del hospital a donde se trasladó al enfermo. El registro de pacientes y su traslado a los hospitales cubre el periodo más crudo de la epidemia, entre octubre de 1915 y octubre de $1916 .{ }^{13}$ Las estadísticas publicadas y el libro o padrón de enfermos se confrontan con un primer sondeo derivado del análisis de 1688 actas del registro civil de defunciones de la ciudad de México, el cual cubre del 21 de septiembre al 31 de diciembre de 1915, datos que por cierto se encuentran disponibles en las actas digitalizadas de la colección www.familysearch.org.search.collection. Estas tres fuentes de información permiten conocer los gru-

${ }^{13}$ Esta relación y padrón de enfermos se encuentra en dos voluminosos cuadernos titulados "Libro de traslados de enfermos infecto-contagiosos. Contiene nombre, enfermedades, domicilios, procedencia, destinos, observaciones, la mayor incidencia es de tifo, octubre de 1915 a octubre de 1916”. Esta información se encuentra en AHSSA, Salubridad Pública. Epidemiología, c. 11, exps. 1 y 2. 
pos de edad afectados, el sexo, la condición socioeconómica y la residencia.

El segundo tipo de fuentes analizadas es la información de carácter cualitativo derivada de las inspecciones sanitarias; de las sesiones del Consejo Superior de Salubridad; de los informes locales de los agentes de policía e inspectores sanitarios de los cuarteles de la ciudad, así como de las municipalidades en donde comenzaron a presentarse los primeros reportes de tifo. ${ }^{14}$ Otras fuentes de gran valía son las publicaciones de la prensa (El País, The Mexican Herald, La Patria y El Demócrata). El análisis de la prensa es confrontada con las fuentes de archivo en virtud de que algunos periódicos dejaron de publicarse, además de que durante el gobierno autoritario de Huerta la prensa fue censurada y controlada por el gobierno. De particular interés es el periódico El Demócrata, que se convirtió en un medio de difusión de la campaña sanitaria, de publicación de artículos científicos, de remedios para prevenir la epidemia, pero sobre todo sirvió como una pantalla de elogio a la actuación del general José María Rodríguez al frente del Consejo Superior de Salubridad.

\section{LA ETIOLOGÍA DEL TIFO:}

LA FIEBRE DEL HAMBRE Y LAS TRINCHERAS

El tifo ha mantenido una presencia recurrente en México. Durante gran parte del virreinato y hasta el siglo xx se pue-

${ }^{14}$ Esta documentación se encuentra en los siguientes acervos documentales. AHDF, Consejo Superior del Gobierno del Distrito. Policía. Salubridad. Epidemias, Sección Tercera, Gobierno del Distrito, Ayuntamiento. Gobierno del Distrito. Obras Públicas. AHSSA, Salubridad Pública. Epidemiología y Salubridad Pública. Presidencia. Actas de Sesión. 
de considerar como una endemia. ${ }^{15}$ Sin embargo, en algunos años podemos observar su manifestación epidémica, cuando afectaba y se propagaba en ciudades y poblaciones. Este padecimiento mantiene una estrecha relación con el ecosistema, las condiciones de vida, en particular con las sanitarias, los hábitos y costumbres de la población. Los enfrentamientos militares y la movilización de tropas han sido un vehículo de propagación del tifo. ${ }^{16}$

Se dispone de estudios que muestran mapeos de la diseminación del tifo en el mundo durante la segunda guerra mundial. En México, al igual que en Europa, Sudamérica y Asia, se observa la presencia del tifo murino y exantemático epidémico con distintos grados de intensidad; muchas de sus manifestaciones estan asociadas a conflictos armados, pobreza y hambre. En España las epidemias de tifo exantemático transmitido por rickettsias se vinculan con el nivel alimenticio e higiene de la población. Por lo anterior, en la Inglaterra de los tiempos modernos era conocido como la fiebre del hambre, padecimiento que provocaba el mayor número de víctimas entre los grupos más pobres, principalmente en vagabundos y mendigos. ${ }^{17}$

${ }^{15}$ En relación con la posible presencia del tifo en la época prehispánica, véase Márquez Morfín, La desigualdad ante la muerte, pp. 215225. Sobre la presencia del tifo durante la colonia y su vinculación con el matlazahuatl, véanse León, “Qué era el matlazahuatl”, I, pp. 383-397; Cuenya, Puebla de los Ángeles y Molina del Villar, La Nueva Espa$\tilde{n} a$, pp. 53-134.

16 Márquez Morfín, La desigualdad ante la muerte.

17 En Europa los registros más antiguos de la enfermedad están fechados a fines del siglo xv, específicamente durante la guerra de Granada en 14891490, momento en el que murieron 17000 españoles con síntomas similares al tifo. Esta cifra significó seis veces más respecto al total de víctimas 
Como ya se dijo, en nuestro país el tifo murino y el epidémico estuvieron presentes a lo largo del siglo xix. En la primera década de este siglo se registró una epidemia con características similares al tifo epidémico, que llamaron la epidemia de fiebres misteriosas. En 1812 este padecimiento se propagó durante los conflictos bélicos de la guerra de Independencia. En febrero de ese año, en el sitio de Cuautla, la situación de los insurgentes se deterioró debido a la falta de alimentos y agua. Estas circunstancias originaron el desencadenamiento de una fuerte epidemia que fue muy severa, pues encontró condiciones adecuadas para desarrollarse. La iglesia y convento de San Diego se improvisaron como hospitales y diariamente morían allí de 25 a 30 personas. A fines de abril el número de enfermos ascendió a 800 . Al ser tomada Cuautla por el ejército realista, se encontró un escenario desolador: "casas destruidas, gente macilenta, cadáveres, conventos y casas llenos de enfermos". ${ }^{18}$

Los brotes epidémicos de tifo también guardan una fuerte relación con el nivel alimenticio de una población. En el caso de México, un buen ejemplo fueron las epidemias de fiebres misteriosas de 1812 aludidas antes y la de tifo de 1915-1916,

acaecidas en las batallas contra los moros. El tifo continuaría presentándose en el viejo continente en 1528 y en 1812, durante la catastrófica expedición de Napoleón a Rusia. Pérez Moreda, Las crisis de mortalidad, pp. 71-72; Harden, “Typhus, Epidemic”, pp. 1080-1084.

${ }_{18}$ Márquez Morfín, La desigualdad ante la muerte, pp. 225-226. Por medio de los informes del general Félix María Calleja al virrey Francisco Javier Venegas, así como de diversas misivas de autoridades locales, María del Carmen Sánchez Uriarte analiza las repercusiones de esta epidemia de fiebres misteriosas en un momento crítico debido a los enfrentamientos militares entre las fuerzas insurgentes y realistas. SÁNCHEZ URIARTE, "Entre la salud pública", pp. 51-74. 
pues ambas fueron antecedidas por escasez y falta de alimentos. ${ }^{19}$ En el primer caso hubo un retraso de lluvias durante mayo de 1809, lo que provocó que los sembradíos no maduraran. A la falta de agua se sumaron heladas anticipadas y granizo en agosto y septiembre. La capital del virreinato y otras localidades del centro padecieron escasez y carestía de alimentos. Años más tarde, las mismas localidades del centro de México sufrieron el embate de la devastadora epidemia, cuyas principales rutas de diseminación correspondieron a los movimientos de las tropas insurgentes. ${ }^{20}$

De manera casi similar a la epidemia de 1812, el brote del tifo en 1915 y 1916 fue antecedido por escasez y carestía de alimentos en las ciudades. Cabe indicar que durante la guerra civil uno de los sectores más afectados fue el comercio interior, ya que en cinco años de lucha hubo severos daños a los ferrocarriles, la agricultura, la ganadería y la industria. Muchas zonas del país quedaran totalmente aisladas, pues las diversas facciones contendientes hicieron volar puentes, quemar durmientes y levantaron vías. ${ }^{21} \mathrm{La}$ consecuencia inmediata para la población, además del miedo y el asalto, fueron el hambre, el desabasto de alimentos y la aparición de diversas enfermedades infecciosas, como la viruela, la escarlatina

${ }_{19}$ Existe un vacío en la historiografía de la revolución mexicana en torno del análisis sistemático sobre el impacto de la epidemia de tifo de 19151916, la cual es referida en múltiples estudios sobre este periodo de la historia de México. Un antecedente importante del análisis presentado en este artículo es el trabajo de María Eugenia Beltrán Rabadán. Véase BELTRÁN RABADÁN, “La epidemia”, pp. 161-180.

20 Florescano y San Vicente, Fuentes; García Acosta, Pérez ZevaLlos y Molina Del Villar, Desastres agrícolas.

${ }^{21}$ UlloA, "La lucha armada", p. 787 e Historia de la revolución mexicana, vol. 6, p. 199; KNIGHT, La Revolución mexicana, vol. II, pp. 580-581. 
y el tifo; este último padecimiento - como ya referimos-, asociado con la pobreza, la desnutrición y la insalubridad. Aunque el tifo afectaba a todos los sectores sociales, el padecimiento estuvo asociado a los cuarteles, los navíos, prisiones, asilos, lazaretos, lugares en donde las personas vivían hacinadas y sin higiene. Como veremos más adelante, estos lugares fueron objeto de constantes inspecciones sanitarias. ${ }^{22}$

Durante 1915 y 1916 el tifo adquirió proporciones epidémicas. Cabe indicar que este padecimiento ya había aumentado su virulencia a partir de 1911, cuando los casos en la ciudad de México se incrementaron de forma significativa. ${ }^{23}$ Sin embargo, no fue sino hasta agosto de 1915 cuando el número de enfermos y muertos aumentó, momento que coincidió con una nueva crisis política y con cruentos conflictos armados que provocaron una gran movilización de tropas y de personas que se refugiaron en la capital. En su forma epidémica, el padecimiento se propaga en la temporada de frío y alcanza su máxima mortalidad a fines del invierno y principios de la primavera. Esta estacionalidad se muestra en la gráfica 1, en la que apreciamos cómo entre 1912 y 1915 los casos de tifo aumentaron respectivamente durante el otoño e invierno. En su estudio sobre el tifo en Puebla, Miguel Ángel Cuenya muestra cómo a partir del mes de octubre de 1915 las rickettsias aumentaron su actividad elevando el número de defunciones. En el caso de la ciudad de México, en 1915 detectamos el mismo patrón, pues en octubre se incrementó el número de enfermos. En Puebla los niveles de pobreza eran más notorios, especialmente entre

22 Carrillo, “Del miedo”, pp. 115-117.

23 Molina del Villar, “De la incertidumbre”, pp. 127-160. 
aquellos que arribaban del campo en busca de comida. "Llegan a la ciudad no sólo 'hambreados' sino sucios y llenos de piojos." El frío en el invierno facilitó el contagio. ${ }^{24}$

\section{Gráfica 1}

ESTACIONALIDAD MENSUAL DEL NÚMERO DE ENFERMOS DE TIFO

EN LA CIUDAD DE MÉXICO Y MUNICIPALIDADES, 1912-1915

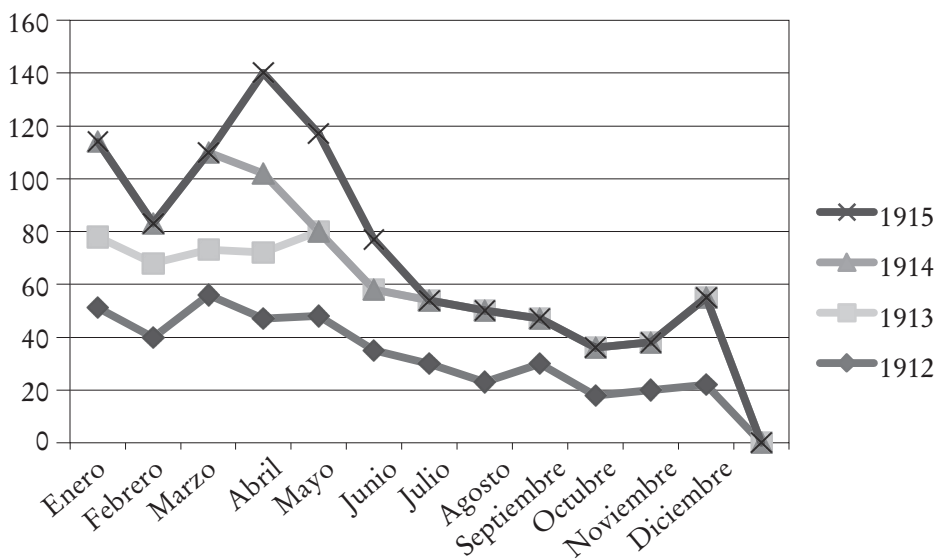

Elaboración propia a partir de AHDF, Consejo Superior del Gobierno del Distrito. Salubridad e Higiene, lib. 646 (1908-1914), exps. 30, 35, 39,44 y 47.

Antes de conocer el impacto del tifo de 1915 y 1916, es necesario referirnos a su etiología. ¿Cuál es la principal diferencia entre el tifo murino y el epidémico? El nombre de tifus endémico fue utilizado por largo tiempo, pero en 1932 Hermann Mooser, un patólogo suizo que trabajó en México, en donde prevalecía esta enfermedad, propuso que esta variante fuera llamada tifo murino. El tifo endémico o muri-

${ }^{24}$ Cuenya, Revolución y tifo, p. 120. 
no es una enfermedad caracterizada por síntomas similares al tifo epidémico. Así, el tifo de Mooser era transmitido por piojos, pero en la medida en que ese vector desaparece, el agente de la enfermedad puede ser la rata negra y se produce lo que se conoce como tifo murino. Este padecimiento se encuentra en todo el mundo y, al igual que el epidémico, se transmite mediante la picadura de la pulga de la rata al hombre, o bien mediante la respiración. Por su parte, el tifo epidémico es causado por la Rickettssia prowasekii y pasa de una persona a otra por medio del piojo del cuerpo humano, Pediculus human corporis, y no tanto por el piojo de la cabeza, Pediculus human capitis. Los dos tipos de infección son transmitidos al hombre por la picadura del piojo o pulga y por las heces infectadas por ambos artrópodos. ${ }^{25}$

El cuadro clínico del tifo aparece tras un periodo de incubación de una a tres semanas. Los primeros síntomas son cefalea, fiebre elevada - mayor de 39 a 40 grados - , escalofríos, postración y mialgias. Lo más frecuente es la aparición de exantemas en axilas, cara, muñecas, tobillos, cara interna de los brazos, abdomen, hombros, tórax, brazos y muslos. El tifo tipo exantemático, en cuyo origen se hallan ciertas rickettsias, estaba estrechamente relacionado con el estado alimenticio de la población y los hábitos higiénicos. ${ }^{26}$ Por su parte, el tifo murino podía transmitirse directamente de la rata al hombre y el piojo humano se encargaba de difundir la infección en forma epidémica. En este caso, el contagio podía ocurrir por las vías de la mucosa bucal, nasal y ocular. De acuerdo con Márquez Morfín, en este esquema de transmisión

25 Harden, “Typhus, Murine”, p. 1085;“Thyphus, Epidemic”, p. 1080.

26 Pérez Moreda, Las crisis de mortalidad, pp. 71-72. 
el tifo murino adquiría proporciones epidémicas si aparecía en una población parasitada y en condiciones anormales, como las guerras o migraciones masivas de refugiados. ${ }^{27}$

A continuación veremos cómo este conjunto de variables afectaron la vida cotidiana de los citadinos en un entorno de gran desasosiego social. Para ello es necesario, primero, referir a las estadísticas de muerte y enfermedad de este padecimiento.

LA CRISIS EN EL GOBIERNO Y LAS ESTADÍSTICAS DE ENFERMOS Y MUERTOS POR TIFO, 1915-1916

La crisis política y la guerra civil afectaron de diversas formas la vida cotidiana de los habitantes de la capital. Como veremos más adelante, el brote violento de tifo que se presentó en agosto de 1915 fue precedido por un año de gran inestabilidad social debido a la crisis política derivada del golpe de estado de Huerta, lo que sin duda repercutió negativamente en el levantamiento de las estadísticas de enfermos y muertos, así como en las campañas sanitarias. Huerta gobernó hasta julio de 1914, cuando fue derrotado por Venustiano Carranza. Al entrar triunfantes las fuerzas constitucionalistas en la ciudad de México en agosto de 1914, el presidente del Consejo Superior de Salubridad, Ramón Macías, declaró a la prensa sobre algunos problemas vinculados con los cambios de funcionarios y la supresión de partidas presupuestales a algunos ramos de sanidad. Durante el gobierno de Huerta dejaron de actuar los inspectores sanitarios y por esta circunstancia el Congreso eliminó su respectiva asignación presupuestal. En palabras textuales, el doctor Macías opinó lo siguiente:

27 Márquez Morfín, La desigualdad ante la muerte, p. 221. 
[...] Semejante acuerdo de la Cámara, al suprimir esa importante dependencia, [los inspectores de sanidad] fue sencillamente un disparate, [pues nos dice], los casos infecciosos de diferentes índole, han aumentado a la espantosa cifra de un $80 \%$ más con respecto a la estadística tomada antes de la supresión, pues no existiendo los inspectores de sanidad las enfermedades se han extendido de una manera escandalosa, constituyen una seria amenaza para la sociedad. ${ }^{28}$

Después de esta breve interrupción, los inspectores de sanidad volvieron a sus funciones en enero de 1915 y su desempeño fue primordial para identificar los lugares en donde había problemas de insalubridad y brotes epidémicos. En cada cuartel y municipalidad había inspectores sanitarios. Estos funcionarios eran médicos y eran nombrados o ratificados en las sesiones del Consejo Superior de Salubridad. Por ejemplo, en la sesión celebrada el 27 de enero de 1915, se nombró a los médicos Francisco Domingo y Carlos Glas inspectores sanitarios de las municipalidades de Azcapotzalco y Milpa Alta, respectivamente. ${ }^{29}$ En una de las sesiones del Consejo Superior de Salubridad podemos vislumbrar la importancia de sus labores para detectar a tiempo un probable brote epidémico:

Ruego a los señores vocales que procuren tomar especial empeño, ya sea dirigiéndose a los señores inspectores de cuartel o ya haciendo visitas a los cuarteles que están a su cargo, para

${ }^{28}$ El Liberal (25 ago. 1914), p. 5. Este periódico fue editado después de la supresión de El Imparcial y su formato era similar.

29 AHSS, Salubridad Pública. Consejo Superior de Salubridad. Presidencia, "Actas de la sesión del Consejo Superior de Salubridad, sesión celebrada el 27 de enero de 1915”. 
investigar si hay focos de infección, para [...poner] en juego el Departamento de Desinfección, levantar una buena parte de esas inmundicias y desinfectar todo lo que sea posible, tratando de hacer esto tanto en la ciudad como en las municipalidades, pues creo que sería la única manera de contrarrestar este mal. Tanto la falta de higiene como el periodo revolucionario por que atravesamos, acumulando en la ciudad y sus alrededores numerosos ejércitos, contribuyen poderosamente al desarrollo de las enfermedades infecto-contagiosas. ${ }^{30}$

A la interrupción de las labores de los inspectores y funcionarios del Consejo Superior, se sumó el hambre en medio de una especie de estado de sitio de la ciudad, debido a la gran cantidad de militares que resguardaban sus alrededores. A fines de 1914 se registró otro momento de inestabilidad, ya que Carranza no logró afianzarse en la capital y la sede de los poderes federales se trasladó a Veracruz para asegurar de armas y provisiones al ejército. Un nuevo asedio sobrevino cuando el Jefe constitucionalista desconoció los acuerdos de la Convención de Aguascalientes y se enfrentó contra las fuerzas villistas y zapatistas, las cuales avanzaron y tomaron el poder de la capital en diciembre de 1914. El mando del país quedó a cargo de Eulalio Gutiérrez. Para el año siguiente los villistas-zapatistas dominaban los estados de Morelos, Puebla, Guerrero y Chihuahua, así como gran parte de Coahuila, Nuevo León, Durango y Zacatecas. ${ }^{31}$

${ }^{30}$ AHSSA, Salubridad Pública. Presidencia. Consejo Superior de Salubridad. "Acta de la sesión del Consejo Superior de Salubridad, sesión celebrada el 30 de marzo de 1915".

31 UlloA, "La lucha armada", pp. 796-798. 
Estos años se caracterizaron por la escasez y carestía de alimentos en la ciudad de México. Rodríguez Kuri revela de qué manera la ciudad padeció diversas protestas sociales por la falta de circulante con el cambio de gobierno, saqueo de comercios, molinos de granos y alimentos. El desabasto de alimentos se agravó a unos meses del brote de tifo. En junio de 1915 en el mercado de La Lagunilla "la gente enardecida no podía contenerse y se precipitó en masa para saquear las tiendas de los alrededores”. Saquearon los mercados de San Cosme, La Merced, San Juan y Martínez de la Torre. ${ }^{32}$ El hambre y la desesperación cundieron por la ciudad, tal como podemos observar en diversas noticias publicadas en la prensa. Así, en mayo de 1915, a unos meses del estallido de la epidemia, se informaba que en las tiendas de abarrotes y expendios de semillas se agotó el maíz. Se calcula que en una mañana más de 4000 personas lograron obtener provisiones de maíz. Algunas personas aseguraron que ya se habían registrado en la capital muertes por inanición, principalmente entre ancianos y niños que habitaban en los barrios bajos, como las colonias La Bolsa, Tepito y La Viga, lugares que - como veremos más adelante - también fueron muy afectados por la epidemia de tifo. ${ }^{33}$

El año de 1915 "fue duro para la gente” debido a que la moneda era un caos, los alimentos no llegaban a la ciudad, los precios subieron de manera alarmante y las enfermedades volvieron. ${ }^{34}$ En el transcurso del primer semestre de 1915 la Convención asumió el gobierno provisional del país y el

\footnotetext{
32 Rodríguez Kuri, Historia del desasosiego, pp. 132-133.

33 The Mexican Herald, ciudad de México, año XX, núm. 7197 (23 mayo 1915), pp. 1 у 3.

34 KNIGHT, La Revolución mexicana, vol. II, p. 866.
} 
poder Ejecutivo quedó a cargo de los villistas, que tuvieron gobiernos efímeros ante nuevas embestidas de las fuerzas constitucionalistas. El 13 de junio se aproximó a la ciudad de México el ejército de Carranza al mando de Pablo González, quien volvió a recuperarla el 2 de agosto de 1915. Lo anterior después de algunas batallas contra los zapatistas y del temor que provocó una columna villista proveniente de Aguascalientes. ${ }^{35}$

Y fue precisamente en agosto de 1915 cuando el tifo comenzó a aumentar en la ciudad de México. Como ya se dijo, entre 1914 y 1915 se suscitaron varias movilizaciones de soldados pertenecientes a grupos rivales con el fin de apoderarse militarmente de la ciudad de México. Los combates y las luchas fueron empeorando las condiciones sanitarias. A principios de 1915 los miembros del Consejo Superior de Salubridad se alarmaron ante nuevos brotes de tifo, por lo que los médicos advirtieron de este problema e iniciaron las inspecciones a distintos barrios y municipalidades que registraron casos de tifo y de otras enfermedades infecciosas. En una de las primeras sesiones del Consejo, en enero de 1915, nueve funcionarios y encargados del mismo órgano sanitario, entre los que se encontraba el doctor Domingo Orvañanos, ${ }^{36}$ informaron que se tenían reportes de que en

35 UlloA, "La lucha armada", p. 798. Sobre el periodo del gobierno de la Convención en la ciudad de México, véase Ávila, "La ciudad de México", p. 3 .

${ }^{36}$ Domingo Orvañanos (1873-1919) fue un destacado médico, higienista y científico porfirista. Tuvo una extensa y variada producción que se publicó en La Gaceta Médica de México. Su mayor obra es Ensayo de Geografía Médica y Climatológica de la República Mexicana, realizada por orden y bajo el auspicio de Porfirio Díaz y publicada en 1889 por la Secretaría de Fomento. Orvañanos tuvo una colaboración cercana con Eduar- 
la municipalidad de San Ángel, en los pueblos de Contreras y La Magdalena, se había desarrollado una "pequeña epidemia". Lo anterior debido a que en los combates que hubo en la serranía habían quedado muchos cadáveres insepultos, por lo que "la materia orgánica en descomposición modificó las condiciones sanitarias". Hasta el momento se habían identificado 8 o 10 enfermos de tifo y otros tantos de viruela. Se ordenó incinerar los cadáveres y enviar personal del Departamento de Desinfección. Al respecto, el doctor Orvañanos dirigió una circular para enviar un vacunador e informar al inspector sanitario de la municipalidad que debían procurar el aislamiento y traslado de enfermos. ${ }^{37}$

En octubre de 1915 el mismo Orvañanos aseveraba que la principal causa de la epidemia había sido el arribo del ejército constitucionalista a la capital, en virtud de que algunos soldados enfermos de tifo diseminaron el contagio en los carros en donde fueron recluidos. De acuerdo con la estadística disponible hasta el momento, $50 \%$ de los enfermos eran militares o bien sus familiares. La escasez de alimentos, el "desaseo de la ciudad" durante la permanencia de los zapatistas, eran considerados por este médico como el principal factor del incremento de casos de tifo, enfermedad endémica en la capital y que siempre se agudizaba en el mes de noviembre. ${ }^{38} \mathrm{Sin}$

do Liceaga, presidente del Consejo Superior de Salubridad durante 27 años, hasta 1914. Gudiño Cejudo, “Domingo Orvañanos", pp. 377-381. 37 AHSSA, Salubridad Pública, Presidencia. Consejo Superior de Salubridad", "Actas de la sesión del Consejo Superior de Salubridad”, sesión celebrada el 2 de enero de 1915.

38 AHSS, Salubridad Pública. Presidencia, Consejo Superior de Salubridad, "Acta de la sesión celebrada el 30 de octubre de 1915, siendo presidente el doctor A. de Luca”. 
embargo, el autor alertaba que la curva no había vuelvo a su nivel normal y - como veremos en distintos momentoslos casos de tifo no sólo no disminuyeron sino que aumentaron de manera sorprendente en los meses siguientes.

El hacinamiento en ciertos lugares fue considerado un factor en el contagio del padecimiento. Los médicos y funcionarios del Consejo señalaban que en los dos últimos años había habido un aumento intempestivo de población debido a la "acumulación de tropas en la capital y la traída de enfermedades por los ejércitos". Los problemas políticos y militares habían dificultado contar con una estadística confiable del número de enfermos y muertos, hecho que comprobamos en esta investigación. Aunque algunos miembros del Consejo señalaban que los datos de mortalidad procedían del Registro Civil y eran confiables porque se prohibían las inhumaciones clandestinas, la publicación del registro seriado y continuo se interrumpió a consecuencia de la guerra. Algunos miembros de esta instancia dieron el ejemplo de los combates acaecidos durante la Decena Trágica, en virtud de que se incineraron individuos sin identificar. ${ }^{39}$

En estos meses de gran incertidumbre social y política observamos cierta alerta por parte de los médicos y miembros del Consejo Superior ante la eminencia de una epidemia de tifo. Como se ha referido, algunos de ellos informaron de brotes o de la aparición de una "pequeña epidemia" en algunos cuarteles y municipalidades, así como de contagios entre miembros de los ejércitos contendientes. Se podía pensar que se trataba de un comportamiento habitual del padeci-

39 AHSSA, Salubridad Pública, Presidencia. "Actas de la sesión del Consejo Superior de Salubridad”, sesión celebrada el 20 de enero de 1915. 
miento, en virtud de que a fines del otoño aumentaba su virulencia. Sin embargo, la curva de enfermos no disminuyó y empezaron a registrarse muertes, como veremos a continuación.

\section{LOS MUERTOS Y ENFERMOS DE TIFO}

Antes de adentrarnos en el impacto demográfico del tifo, es importante señalar que su estudio, al igual que el de otras epidemias ocurridas en estos años de conflictos armados, conlleva diversas aristas, debido a la insuficiencia y poca confiabilidad de las fuentes estadísticas disponibles. Desafortunadamente y por la misma situación desencadenada por la guerra no disponemos de información sobre el número de habitantes en la capital del país en 1915. ¿Cuántos habitantes había en la ciudad de México antes de 1915? El dato más cercano previo al tifo de ese año es el de 1910, cuando la población del Distrito Federal ascendía a 720753 habitantes. Esta cifra comprendía los habitantes de las municipalidades de Azcapotzalco, Guadalupe Hidalgo, Mixcoac, Iztapalapa, Tacuba, Tacubaya, Cuajimalpa, San Ángel, Coyoacán, Xochimilco, Tlalpan y Milpa Alta. Por su parte, en la ciudad de México, que comprendía los ocho cuarteles, vivían 471066 habitantes, es decir, $65.3 \%$ del total de la población residía en el antiguo casco urbano y las nuevas colonias fundadas alrededor. ${ }^{40}$

Cabe indicar que esta proporción entre la población residente en los cuarteles y municipalidades se refleja en nuestras estadísticas de enfermos de tifo de febrero a diciembre

${ }^{40}$ González Navarro, Población y sociedad, pp. 31-52. 
de 1916 , en virtud de que $79.7 \%$ de los mismos procedía de los ocho cuarteles mayores de la ciudad y $20.2 \%$ de las municipalidades, lo que en números absolutos significaba respectivamente 8084 y 2056 enfermos. ${ }^{41}$ Por lo tanto, podemos presumir que el mayor número de contagios se presentó en el antiguo casco urbano, en donde la población vivía más concentrada y hacinada en las viviendas.

Es posible que en 1915 la población haya aumentado en la capital debido a que durante los conflictos armados mucha gente del interior emigró a la ciudad de México y se refugió en los barrios y colonias de los alrededores. El aumento de habitantes, principalmente a partir de 1913, al extenderse la Revolución, hizo que la capital se congestionara con una población flotante y después definitiva. ${ }^{42}$ Ante este panorama, uno de los principales inconvenientes para evaluar las repercusiones demográficas de las epidemias, el hambre y la guerra es la dificultad de disponer de un censo o fuente estadística confiable.

De tal suerte que un tema importante en la historiografía de la revolución mexicana es conocer con precisión el impacto demográfico de los conflictos armados, del hambre y las enfermedades. Al respecto, Ordorica y Lezama, en un interesante artículo se cuestionan sobre el costo de la guerra civil en términos de vidas humanas y de la redistribución de la población en el territorio. También se tienen dudas en relación con los cambios en los patrones de natalidad a consecuencia de las batallas militares, así como del

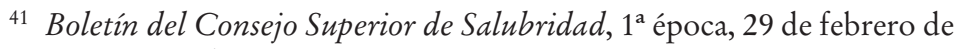
1916, núms. 2 al 12.

${ }^{42}$ González Navarro, Población y sociedad, p. 147. 
comportamiento de la natalidad, la mortalidad y la migración. El análisis de estos fenómenos, que resultan fundamentales para conocer el crecimiento de la población, se enfrenta al problema de las deficiencias de los censos correspondientes al periodo de 1910 a $1921,{ }^{43}$ aspecto que de algún modo comprobamos en nuestro trabajo al comparar distintas fuentes de información.

De manera similar a las estimaciones sobre la caída de la población indígena en el momento del contacto europeo, ${ }^{44}$ los estudiosos dan cuenta de distintas cifras sobre las pérdidas de vida ocurridas durante los años de la Revolución. Las estimaciones fluctúan entre 1 y 2000000 de muertes a consecuencia de la guerra, el hambre y las enfermedades. ${ }^{45} \mathrm{Al}$ igual que en el periodo del contacto europeo y colonial, aquí nos enfrentamos a un problema similar en cuanto a la disponibilidad y confiabilidad de las fuentes, en virtud de que se han

43 Ordorica y Lezama, “Consecuencias demográficas”, p. 38.

44 Sobre este debate y las múltiples causas de la catástrofe demográfica a consecuencia de la conquista, véase Lrvi BACcI, "Las múltiples causas", pp. 31-48.

45 De acuerdo con los datos arrojados por los censos de 1910 y 1921, la población de México pasó de 15160369 a 14334780 habitantes. A partir de esta cifra se dispone de diferentes estimaciones sobre el número de decesos provocados por la guerra civil, la mortandad infantil y las epidemias. Gilberto Loyo señala que fallecieron 2000000 de personas, mientras Robert Greer considera que fueron 75100. Para Gamio 300000 muertos se debieron "a la influenza española y a un número indefinido de defunciones por el tifo y la desnutrición”. Estas diferencias derivan de que los censos anteriores a 1921 sobreestimaron la población, en tanto que este último la subestimó. Sobre este debate, véase ORDORICA y LezAma, “Consecuencias demográficas”, pp. 40-41. Sobre las inconsistencias y omisiones del censo de 1921, véase GREER, “The Demographic Impact”, pp. 39-57. 
hecho cálculos de las bajas demográficas a partir de la comparación simple de dos censos, el de 1910 y 1921, que revelan diversas inconsistencias. ${ }^{46}$

El trabajo de Ordorica y Lezama presenta un enfoque novedoso, pues señalan que el análisis demográfico debe considerar el impacto de la revolución mexicana sobre cada uno de los componentes que determinan la estructura, la dinámica y el crecimiento de la población, es decir, desde una perspectiva demográfica. En este sentido, nos parece pertinente recurrir al enfoque local e integral del impacto de la epidemia, mediante la exploración de distintas fuentes de información. Nuestro objetivo es mostrar que el tifo de 1915 y 1916, así como su manifestación endémica, contribuyó al saldo total de muertos durante estos años de conflicto armado. Más allá de obtener cifras exactas de la mortandad provocada por esta enfermedad, nos interesa ofrecer una primera

${ }^{46}$ El censo de 1921 se vio afectado en su organización a consecuencia de las limitaciones de un personal escaso y mal preparado, además de que -como se tenía previsto- en 1920 no se efectuó por a la caída de Carranza. Finalmente el censo se realizó en noviembre de 1921, con el gobierno de Obregón. Un gran problema fue el cambio frecuente de autoridades, la falta de cooperación de los gobiernos locales, la incomunicación de las localidades y la inseguridad. Tanto el censo de 1910 como el de 1921 se hicieron sobre bases territoriales diferentes. Respecto al de 1910, Greer muestra que éste se sobreestimó porque el gobierno federal se sentía obligado a exhibir un incremento en el número de habitantes como prueba del progreso del país, mientras las autoridades locales aumentaban la cifra de habitantes con el objeto de exagerar el número de sus diputados federales. Por su parte, el censo de 1921 acusa un fuerte subregistro, debido a que por la misma situación de inestabilidad política se dejó de enviar la información censal. González Navarro, Población y sociedad, pp. 36-37; Ordorica y Lezama, "Consecuencia demográficas", p. 39. Véase el capítulo 3 del estudio de Greer, "The Demographic Impact”, pp. 22-57. 
aproximación de sus efectos por grupos de edad y mostrar, al mismo tiempo, que la misma se presentó junto con otras enfermedades infecto contagiosas, las cuales provocaron gran número de decesos entre la población infantil y adulta.

Como hemos advertido, otra consecuencia de los conflictos militares y políticos fue la falta de una serie continua de la estadística de muertos y enfermos por tifo en la ciudad de México. ${ }^{47}$ Ante la ausencia de una estadística seriada de la mortalidad y morbilidad, los médicos hicieron estimaciones aproximadas. Por ejemplo, Ocaranza afirmó que en 1916 se infectaron alrededor de 10000 habitantes. Por su parte, el doctor Silvino Riquelme señaló que entre noviembre de 1915 y mayo de 1917 se habían contagiado cerca de 21344 individuos, de los cuales 2119 murieron..$^{48}$ Estas estimaciones no permiten llegar a conclusiones firmes sobre el impacto demográfico de esta epidemia. Una de las principales dificultades consiste en confrontar estas cifras con algunas publicadas a partir de fuentes de otra naturaleza, como el registro civil o estadística de los panteones. Otro problema es el vacío de información de los meses previos al brote violento de tifo en agosto de 1915. Cabe indicar que el Boletín del Consejo Superior dejó de publicarse en 1914 y 1915. De las pocas estadísticas disponibles en el primer año tenemos las de la primera semana de noviembre, cuando la prensa publicaba que según informes del Consejo los casos de tifo, viruela y escarlatina habían disminuido: tifo 25 casos, escarlatina 10 y viruela 6 . Se señalaba que en las municipalidades de

47 Al respecto, González Navarro señala que la Revolución afectó la recopilación de todas las estadísticas, especialmente en el periodo de 1914-1916. González Navarro, Población y sociedad, p. 31.

${ }^{48}$ En Tenorio, "De piojos", p. 28. 
Tacuba, Mixcoac, Guadalupe y Xochimilco se habían reportado casos de viruela y escarlatina, pero sólo uno de tifo. ${ }^{49}$

En 1916 el Boletín volvió a publicar su estadística de mortalidad y morbilidad. A partir de esta publicación mensual logramos relacionar el número de enfermos y muertos durante este año, además de distinguir la morbilidad por sexo y grupos de edad. ${ }^{50} \mathrm{El}$ problema con esta publicación es que sus datos en ocasiones no coindicen con las estadísticas disponibles en otras fuentes de información, como comunicados semanales del Consejo Superior del Gobierno del Distrito Federal o bien la misma prensa. A veces no se indica la procedencia de las cifras, aunque suponemos que debió provenir de los informes de médicos y hospitales enviados a las instancias de salud local. Empero, esta estadística publicada sí permite reconstruir la estacionalidad de la epidemia en 1916, en la que observamos cómo a partir del otoño e invierno aumentaron los números de casos (gráfica 2).

La estadística de mortalidad y morbilidad disponible en esta publicación mensual también sirvió de base a las estimaciones realizadas por Francisco Valenzuela, médico y jefe del Servicio del Consejo Superior de Salubridad, quien por cierto, años más tarde presentaría en el Congreso Nacional del Tabardillo una ponencia sobre las medidas profilácticas contra la epidemia de tifo, en el que incluye una estadística de enfermos y muertos por tifo en la ciudad de México. ${ }^{51}$

Un aspecto sobre el que debemos llamar la atención y que de algún modo repercutió en la falta de estadísticas conti-

49 El Liberal (10 nov. 1914), p. 8.

50 Boletín del Consejo Superior de Salubridad (ene.-dic. 1916), 1, 2, 3, 4, $5,6,7,8,9,10,11$ y 12 .

51 Valenzuela, “Medidas profilácticas”, pp. 263-271. 


\section{Gráfica 2}

ESTACIONALIDAD MENSUAL DE LA EPIDEMIA DE TIFO DE 1916. TOTAL DE ENFERMOS

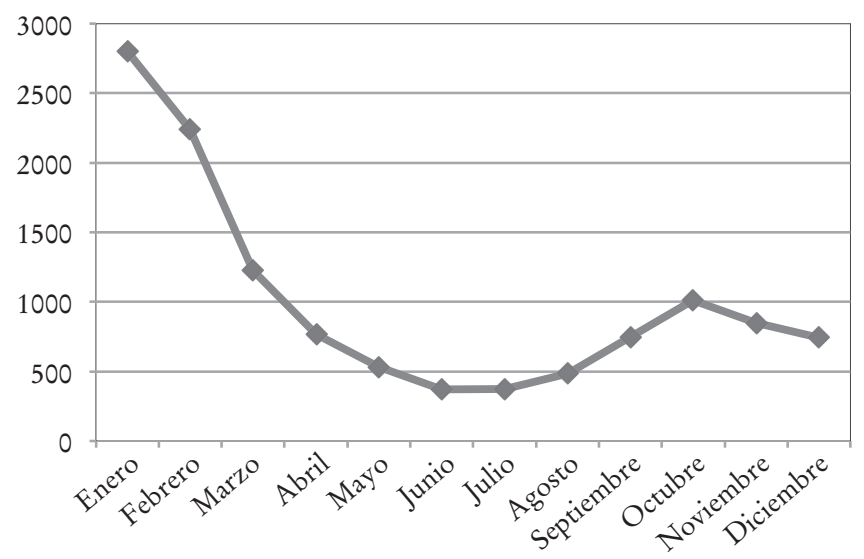

Elaboración propia a partir del Boletín del Consejo Superior de Salubridad, 1 al 12 (ene.-dic. 1916).

nuas de morbilidad previo al brote epidémico fue que antes de 1914 el Consejo Superior de Salubridad era una institución local del Distrito Federal. El ministro de Gobernación consultaba al Consejo en asuntos de higiene pública y de éste dependían las delegaciones sanitarias de puertos y poblaciones fronterizas. ${ }^{52}$ Como veremos más adelante, en el cuadro 1, la estadística de enfermedades entre 1911 y 1914 procede del Archivo Histórico del Distrito Federal, en donde podemos conocer el comportamiento de las enfermedades infecto contagiosas de los residentes de los ocho cuarteles de la ciudad y municipalidades. La situación cambió a principios de 1915, fecha a partir de la cual empezamos

52 Carrillo, “Eduardo Liceaga”, pp. 371-375. 
a identificar vacíos de información e inconsistencias, pues la serie de morbilidad y mortalidad enviada al Consejo Superior del Distrito Federal se interrumpió por algún tiempo.

En suma, el estudio de las repercusiones demográficas del brote de 1915 y 1916 se dificulta debido a vacíos de información que podemos atribuir al golpe militar de Victoriano Huerta, la guerra subsecuente y la salida momentánea del gobierno federal a Veracruz. Sabemos que de repente la información dejó de fluir a las autoridades de salubridad local y se envió directamente al Consejo Superior de Salubridad. Sin embargo, debemos destacar que el arribo del médico y general José María Rodríguez al frente de este organismo de salud llevó a concretar una campaña contra el tifo de una manera más centralizada y enérgica, al parecer como consecuencia del triunfo y afianzamiento del gobierno constitucionalista en el país. Así, Rodríguez nombró al doctor Alfonso Prune$\mathrm{da}^{53}$ al frente de la campaña, la cual se dirigió en dos sentidos: primero, detección y aislamiento y, segundo, difusión por medio del periódico El Demócrata sobre medidas curativas y preventivas contra el tifo. Como ya se indicó, este periódico fue un importante vehículo de promoción de educación a

${ }^{53}$ El médico Alfonso Pruneda (1879-1957) nació en la ciudad de México y fue un promotor de la medicina preventiva, de la educación higiénica y de la salud pública. Ejerció una intensa labor docente en la Escuela Nacional Preparatoria y en Escuela de Medicina. En 1906 fue catedrático de Clínica Médica en el Hospital Juárez. En 1936, en la Universidad Nacional de México fundó la cátedra de Higiene y Medicina. Pruneda consideraba que la educación y la promoción de la salud era la mejor forma de combatir las epidemias. En 1920 organizó exitosas campañas para luchar contra la peste bubónica en Veracruz y la fiebre amarilla en las costas del Golfo y del Pacífico. Agostoni, “Alfonso Pruneda”, pp. 585-589; Agostoni y Ríos Molina, Las estadísticas, p. 167. 
la población para incentivar medidas generales de higiene, al igual que un medio de difusión del conocimiento científico. ${ }^{54}$

Un resultado de la enérgica campaña contra el tifo fue la elaboración de un extenso libro o informe de enfermos infectocontagios, los cuales entre octubre de 1915 y octubre de 1916 fueron trasladados a los hospitales de la ciudad de México. Sin duda, este documento es una muestra del Estado higienista del siglo xix, cuyos rasgos fueron el nacimiento del hospital medicalizado y la preocupación por la cuantificación y el uso de las estadísticas. ${ }^{55}$ En el caso de nuestro estudio, este valioso documento nos permite conocer y cuantificar el número de enfermos de tifo y de otras enfermedades infecto contagiosas durante 1915 y 1916. El análisis de este documento es importante si consideramos la falta de datos seriados y uniformes del número de enfermos y muertos antes y durante la epidemia, principalmente para el primer semestre de 1915, cuanto el tifo comenzó a adquirir proporciones epidémicas. ${ }^{56}$

Como ya se dijo, entre 1914 y agosto de 1915 los datos son parciales y poco confiables. Por ejemplo, contamos con informes enviados al Gobierno del Distrito Federal que muestran diversas inconsistencias, debido a que la estadística oficial sólo cubrió algunos meses del primer semestre, de abril a junio de 1915. Así, se sabe que entre enero y junio de 1915 se notificaron 276 casos de viruela y 175 de tifo, lo que mostró una gran disminución respecto de los años anteriores. Para

\footnotetext{
54 Agostoni, "Popular Health", p. 57.

${ }^{55}$ Caponi, "Miasmas", p. 162.

${ }^{56}$ AHSSA, "Libro de traslados de enfermos infecto-contagiosos. Contiene nombres, enfermedades, domicilios, procedencia, destinos, observaciones, la mayor incidencia es de tifo, octubre de 1915 a octubre de 1916", Salubridad Pública. Epidemiología, c. 11, exps. 1 y 2.
} 
junio sólo se reportaron, en los ocho cuarteles de la ciudad, 19 enfermos de tifo y 17 de viruela. En relación con el tifo sólo hubo una defunción, mientras que a consecuencia de la viruela fallecieron 12 personas, ocho de las cuales eran niños menores de 10 años. ${ }^{57}$ Los datos anteriores harían pensar en una tendencia a la baja en el número de casos de tifo, pero no fue así, como veremos en seguida.

¿A qué se debió esta caída en el número de reportes de enfermos de tifo en la ciudad de México? Además del acusado subregistro por la crisis política, planteamos también que, a pesar de que las campañas sanitarias tuvieron un nuevo aliento a partir de agosto de 1915, el tifo no disminuyó y se propagó con gran celeridad. Logramos identificar que la prensa también omitió algunas notas sobre la gravedad de la epidemia, ya que frente a la llegada del nuevo gobierno constitucionalista las noticias alabaron sus labores altruistas ante el hambre acaecida en los años previos. Precisamente en agosto de 1915, cuando la epidemia comenzaba a cundir, se anunció que el gobierno había suministrado "masa al pueblo". En un encabezado del periódico El Demócrata se leía lo siguiente: "Los artículos de primera necesidad están bajando de precio, tales como el azúcar, el café, arroz, piloncillo y frijol”. En septiembre de 1915 el gobierno dotó de 250 gramos de carne, litros de consomé y pan a los indigentes del Hospital Juárez..$^{58}$

57 AHDF, Consejo Superior del Gobierno del Distrito. Policía. Salubridad. Epidemias. Sección Tercera: Defunciones por tifo, viruela y escarlatina, ciudad de México y municipalidades, 30 mayo a 5 junio de 1915, lib. 3675, exp. 29, 1915.

${ }^{58}$ El Demócrata (14 ago. 1915), p. 1; (16 ago. 1915), p. 1; (17 ago. 1915), p. 1; (18 ago. 1915), p. 4; (27 ago. 1915), p. 3; (1º sep. 1915), p. 4; (4 sep. 1915), p. 1. 
En cuanto a la estadística de enfermos por tifo y otras enfermedades, elaboramos el siguiente cuadro a partir de los informes del Consejo Superior del Gobierno del Distrito y del Consejo Superior de Salubridad. Podemos apreciar el aumento constante del tifo entre 1911 y 1916. Las cifras de 1915 y 1916 provienen del libro del traslado de enfermos infecto contagiosos a los hospitales de la ciudad de México.

\section{Cuadro 1}

TOTAL DE ENFERMOS DE TIFO, VIRUELA Y ESCARLATINA EN

LA CIUDAD DE MÉXICO Y MUNICIPALIDADES, 1911-1916

\begin{tabular}{lrrrc}
\hline Año & Tifo & Viruela & Escarlatina & Total de casos \\
\hline 1911 & 624 & 113 & 56 & 793 \\
1912 & 2040 & 952 & 529 & 3521 \\
1913 & 1422 & 752 & 1188 & 3362 \\
1914 & 1178 & 701 & 516 & 2395 \\
1915 (oct-dic) & 1658 & 45 & 5 & 1708 \\
1916 (enero-oct.) & 9793 & 133 & 31 & 9957 \\
\hline
\end{tabular}

FuEnTE: AHDF, Consejo Superior del Gobierno del Distrito. Salubridad e Higiene, lib. 646, exps. 30, 39, 44 y 47; AHSSA, "Libro de traslados de enfermos infecto-contagiosos. Contiene nombres, enfermedades, domicilios, procedencia, destinos, observaciones, la mayor incidencia es de tifo, octubre de 1915 a octubre de 1916", Salubridad Pública. Epidemiología, c. 11 , exps. 1 y 2.

La drástica caída en el número de enfermos de viruela ocurrió en el segundo semestre de 1915 y fue precisamente en este periodo cuando el tifo comenzó a repuntar. En 1915 y 1916 la epidemia manifestó un gran incremento y las medidas de control sanitario y traslados de enfermos cobraron mayor energía. A fines de 1915 la campaña contra el tifo 
adquirió otro impulso, debido principalmente a la exigente labor de José María Rodríguez en un periodo crítico del país. Ya referimos que este funcionario ordenó llevar a cabo un registro de todos los enfermos de tifo u otras enfermedades infecto contagiosas identificadas por las autoridades de la policía y enviados a los hospitales de la ciudad de México. Se localizaban al enfermo y su familia para hacer la desinfección y se ponía un letrero en la casa que indicaba que el lugar estaba en aislamiento. El enfermo de tifo era denunciado por algún familiar, vecino o conocido para ser aislado en algún hospital de la ciudad. ${ }^{59}$ Cabe señalar que en estas tareas también participaron médicos particulares, agentes sanitarios del Gobierno del Distrito (médicos y policías) y la Beneficencia Pública.

La valiosa información disponible en los libros del traslado de enfermos a los hospitales de la ciudad de México permite hacer comparaciones con las cifras de enfermos y muertos publicadas en los Boletines del Consejo Superior. Salubridad y en el artículo del doctor Francisco Valenzuela. ${ }^{60}$ Cabe señalar que los datos de este último proceden de los informes de enfermos y muertos que se encontraron en los carros de ferrocarril, estaciones, cuarteles y hospitales. Se trataban de "multitudes que llegaban a la ciudad sucias, agotadas y hambrientas", propagando el contagio por todos lados. ${ }^{61}$

\footnotetext{
59 Agostoni y Ríos Molina, Las estadísticas, p. 166.

60 Valenzuela, “Medidas profilácticas”, pp. 263-271.

61 Valenzuela, “Medidas profilácticas”, pp. 265-266. La versión completa del cuadro de enfermos y muertos de tifo elaborado por Valenzuela aparece citado en la tesis de María Eugenia Beltrán Rabadán. BeLtrán RabadÁn, “La epidemia”, p. 31.
} 


\section{Cuadro 2}

NÚMERO DE ENFERMOS Y MUERTOS POR TIFO EN LA CIUDAD DE MÉXICO, 1911-1917

\begin{tabular}{llcccc}
\hline Año & Meses & Enfermos & Muertos & $\begin{array}{c}\text { Enfermos } \\
\text { (promedio } \\
\text { mensual) }\end{array}$ & $\begin{array}{c}\text { Muertos } \\
\text { promedio } \\
\text { mensual) }\end{array}$ \\
\hline 1915 & $\begin{array}{l}\text { Agosto- } \\
\text { octubre }\end{array}$ & 1421 & 280 & 473.6 & 93.3 \\
$1915-$ & $\begin{array}{l}\text { Noviembre- } \\
\text { marzo }\end{array}$ & 9879 & 1833 & 1975.8 & 366.6 \\
1916 & 3278 & 554 & 546.3 & 92.3 \\
1916 & $\begin{array}{l}\text { Abril- } \\
\text { septiembre }\end{array}$ & 2607 & 346 & 869 & 115.3 \\
1916 & $\begin{array}{l}\text { Octubre- } \\
\text { diciembre }\end{array}$ & 4407 & 462 & 367.2 & 38.5 \\
1917 & $\begin{array}{l}\text { Enero- } \\
\text { diciembre }\end{array}$ & 6262 & 1183 & & \\
1915 & 10923 & 1830 & & \\
1916 & 4407 & 462 & & \\
1917 & 21592 & 3475 & & \\
$1915-$ & & & & & \\
1917 & & & & & \\
\hline
\end{tabular}

Elaboración propia a partir de Valenzuela, "Medidas profilácticas", p. 266; Beltrán Rabadán, “La epidemia”, p. 31.

La relación de enfermos y muertos de tifo que aparece en este cuadro permite identificar su estacionalidad mensual. Como se puede apreciar en el cuadro 2, la epidemia fue más intensa en los meses de otoño e invierno, principalmente a partir de noviembre de 1915 y hasta marzo del siguiente año, cuando respectivamente se contabilizaron 9879 enfermos y 1833 muertos. En los meses de primavera y verano los casos disminuyeron. Como se aprecia en la gráfica 3 , 
este comportamiento mensual del tifo también se comprueba en el libro del traslado de enfermos infecto contagiosos a los hospitales de la ciudad de México, en virtud de que entre noviembre de 1915 y marzo 1916 el número de enfermos mantuvo una tendencia al alza y conforme avanzó la primavera empezó a disminuir.

\section{Gráfica 3}

NÚMERO DE ENFERMOS REMITIDOS A LOS HOSPITALES DE LA CIUDAD DE MÉXICO, OCTUBRE DE 1915 A OCTUBRE DE 1916

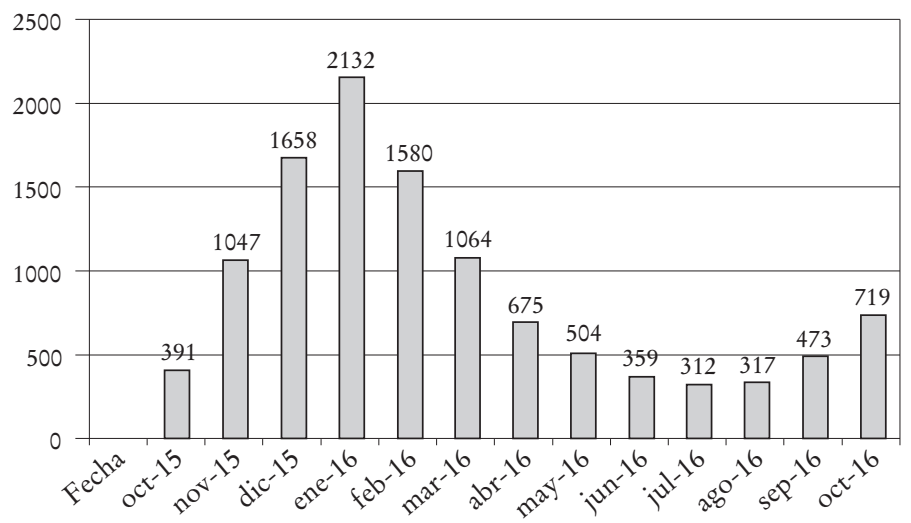

Elaboración propia a partir de "Libro de traslados de enfermos infecto-contagiosos. Contiene nombres, enfermedades, domicilios, procedencia, destinos, observaciones, la mayor incidencia es de tifo, octubre de 1915 a octubre de 1916”. AHSSA, Salubridad Pública. Epidemiología, c. 11, exps. 1 y 2.

Los datos contenidos en este libro de enfermos y en el Boletín comprenden los ocho cuarteles de la ciudad, así como las municipalidades de Azcapotzalco, Coyoacán, Guadalupe Hidalgo, Ixtapalapa, Mixcoac, San Ángel, Tacuba, Tacubaya, Tlalpan y Xochimilco. Cabe señalar que en 
ambas fuentes más de 70\% de los enfermos residían en los cuarteles de la ciudad, lo cual abre una serie de interrogantes. Primero, como ya indicamos, el mayor número de casos quizá obedeció a que gran parte de la población se concentraba en los ocho cuarteles de la ciudad, en donde había más viviendas, mayor hacinamiento e insalubridad. Otra cuestión refiere a que posiblemente haya habido un fuerte subregistro de enfermos en las municipalidades, en donde a lo mejor el control sanitario y el registro de enfermos no se llevaron de manera tan detallada. Hay que recordar que en las sesiones del Consejo Superior de Salubridad los primeros casos de tifo alarmantes ocurrieron en San Ángel y La Magdalena Contreras. A fines de enero de 1915 se designaron los primeros inspectores sanitarios para Xochimilco, Azcapotzalco y Milpa Alta. En Xochimilco, además, la población se quejaba de la calidad del agua, la cual en gran medida abastecía a la capital. ${ }^{62} \mathrm{Su}$ pésimo estado, así como la situación de derrames de atarjeas y caños, fue el causante principal de las enfermedades gastrointestinales que originaron un número considerable de decesos entre 1915 y 1916. Al respecto, Alberto Pani señalaba que el agua potable consumida podía provenir de aguas negras y mostraba "impureza química, biológica y bacteriológica”, hecho que era una de las causas determinantes de la mortalidad y, sobre todo, de la alta morbilidad de la población de la ciudad de México. ${ }^{63}$

${ }^{62}$ A la primera sesión del Consejo asistieron González Fabela, Huici, Ortega, Orvañanos, Morales, Ramírez de Arellano, Ruiz Erdozain, Varela, el presidente y secretario que suscriben. "Acta de la sesión celebrada el 2 de enero de 1915"; “Acta de la sesión celebrada el 20 de marzo de 1915”. AHSSA, Salubridad. Presidencia, Actas de Sesión, año de 1915.

${ }^{63}$ PANI, La higiene, pp. 132-133. 
De acuerdo con el Boletín de Salubridad, en diciembre de 1915 la ciudad de México y sus municipalidades reportaron un total de 3241 enfermos de tifo, mientras en enero y febrero de 1916 fueron respectivamente 2801 y 2240 . Hay que advertir que el primer dato sólo comprende los casos de tifo en la ciudad de México, mientras en febrero se sumaron los enfermos reportados en las 10 municipalidades del gobierno del Distrito Federal. En cuanto a los decesos, se advierte una ligera disminución en enero, pues se reportaron 488, cifra que denotaba un descenso de 213 casos respecto del mes anterior. En febrero el tifo aportó $14.12 \%$ del total de causas de muerte en la capital del país. Las enfermedades respiratorias agudas y gastrointestinales significaron respectivamente 20.64 y $24.75 \%$ de la mortalidad total. ${ }^{64}$

En la gráfica 4 observamos que los meses de enero a marzo de 1916 fueron los más crudos de la epidemia por presentar el mayor número de enfermos y de decesos. El repunte volvió a ocurrir a partir de septiembre, octubre y noviembre de 1916. La información estadística y los reportes tuvieron el visto bueno de Alfonso Pruneda y Francisco Valenzuela, jefes del Servicio de enfermedades transmisibles en distintos momentos. Podemos comprobar que el total de enfermos y muertos no varía mucho entre las publicaciones mensuales del Boletín y el artículo de Valenzuela, aunque el último - como se ha reiterado - no incluyó los datos de las municipalidades. Al igual que las otras fuentes disponibles, en el estudio de Valenzuela se registró un aumento de contagios y decesos en noviembre de 1916, con 1616 enfermos y 336 muertos, cifras que repre-

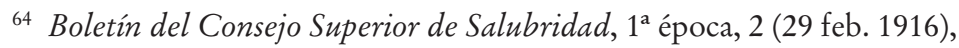
pp. 70-71. 
sentaron un incremento de cerca de 1000 casos de enfermos y más del doble de muertos ocurridos en el mes anterior. Este autor identificó como los meses más severos de la epidemia entre diciembre de 1915 y enero de 1916, cuando respectivamente se registraron 567 y 488 decesos. ${ }^{65}$

\section{Gráfica 4}

TOTAL DE ENFERMOS Y MUERTOS EN LA CIUDAD DE MÉXICO, PRIMER SEMESTRE DE 1916

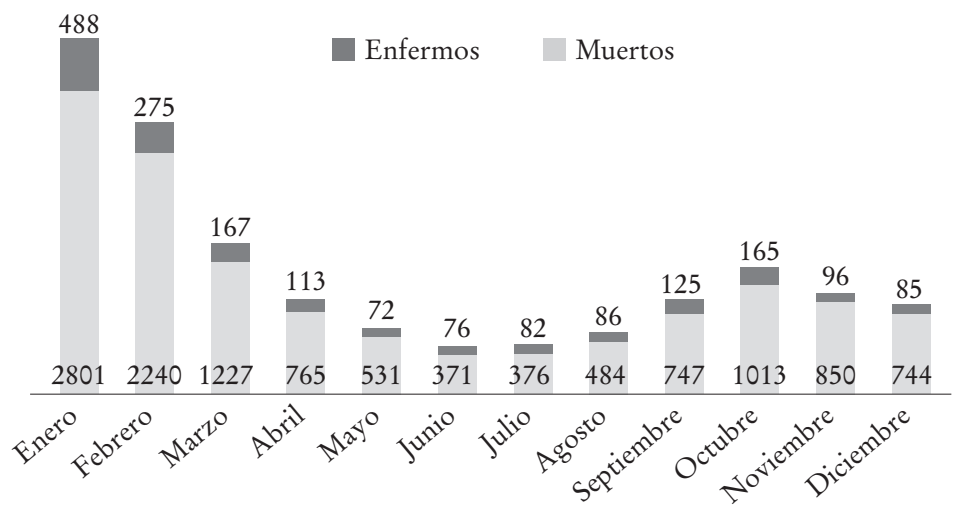

Elaboración propia a partir del Boletín del Consejo Superior de Salubridad, 1, 2, 3, 4, 5 y 6 (ene.-jun. 1916).

En síntesis, y remitiéndonos a los datos de estas publicaciones, en 1915 en la ciudad de México murieron a consecuencia del tifo 1183 personas y al año siguiente 1830. Los datos que aparecen en el artículo de Valenzuela permiten estimar la tasa de letalidad, es decir, el porcentaje de muertes respecto del total de enfermos. Tal operación aritmética arro-

65 Valenzuela, “Medidas profilácticas”, p. 266. 
ja un resultado de $17.53 \% .{ }^{66}$ Contrario a lo que se esperaba, esta tasa no es de las más elevadas, lo que quizá podemos atribuir al éxito de las medidas sanitarias para evitar mayores contagios y al cuidado de los enfermos. Como se aprecia en la gráfica 4, en febrero de 1916, el número de muertos fue elevado y al mes siguiente casi había disminuido a la mitad. De acuerdo con esta información, el número de muertos y de enfermos fue decreciendo significativamente.

Otro aspecto a destacar es que el total de muertos por tifo en la ciudad de México no es muy diferente al registrado en la ciudad de Puebla. Según Cuenya, los datos del registro del Panteón Municipal revelan que en 1915 murieron 999 individuos y en 1916 el número de decesos se elevó a $1076 .{ }^{67}$ Podemos aventurar que la escasa diferencia entre ambas ciudades obedeció a que en la capital del país hubo un fuerte subregistro de muertos y enfermos, o bien -como hemos señaladoal éxito de la campaña sanitaria emprendida por el Consejo Superior de Salubridad. Estas dudas o preguntas surgen principalmente al comparar el total de habitantes entre ambas ciudades, ya que -por mucho- la capital del país tenía más residentes. Por ejemplo, en 1910 en los 16 cuarteles menores de la ciudad de Puebla vivían 101232 personas, mientras en ese mismo año la población de la ciudad de México que

\footnotetext{
${ }^{66}$ La tasa de letalidad es el numerador o número de individuos que mueren durante un periodo específico y el denominador que refiere al número de individuos que fueron diagnosticados con una enfermedad específica. La fórmula es la siguiente:

Letalidad $=$ Número de defunciones por una causa específica $\times 100$

Número de enfermos por la misma causa

Véase García García, "Uso de algunos indicadores", p. 1.

${ }^{67}$ Cuenya, Revolución, pp. 31-52.
} 
comprendía los ocho cuarteles mayores ascendía a 471066 habitantes..$^{68}$ No debemos olvidar que entre más habitantes y condiciones de hacinamiento el tifo cobraba mayor número de víctimas.

Por grupos de edad y por sexo observamos un patrón similar al de la ciudad de Puebla, aunque ahí hubo mayor porcentaje de mujeres fallecidas: 1059 mujeres frente a 1014 hombres. En ambas ciudades el mayor número de muertos se ubicó en las edades de 30 a 50 años. En cuanto a la afectación entre las mujeres, el censo de 1910 señala que $30.9 \%$ de la población total de la ciudad de México eran mujeres entre 15 y 50 años ${ }^{69}$ y del total de muertes, $69.5 \%$ correspondió a mujeres. Esta sencilla comparación no permite medir el impacto real de la epidemia entre la población adulta, pues consideramos que hubo un fuerte subregistro y seguramente este sector aumentó en los años del conflicto armado. En la gráfica 5 vemos que en la capital del país murieron más hombres que mujeres. Es decir, este patrón de mortalidad con mayor afectación entre los hombres coincide con el argumento de Ordorica y Lezama, quienes señalan que durante la Revolución murieron más hombres que mujeres. ${ }^{70}$ Lo anterior seguramente debido al saldo de muertes en los combates, aunque en el caso del tifo podemos suponer que la población masculina estuvo más expuesta al contagio en virtud de que los militares fueron las primeras víctimas del tifo y por su propia movilidad.

${ }^{68}$ Cuenya, Revolución, p. 14; González Navarro, Población y sociedad, pp. 31-52.

${ }^{69}$ En 1910 la población femenina de entre 15 y 50 años ascendía a un total de 223125 personas. Estadísticas, p. 33.

70 Ordorica y Lezama, “Consecuencias demográficas”, p. 42. 


\section{Gráfica 5}

TOTAL DE MUERTOS POR LA EPIDEMIA DE TIFO EN LA CIUDAD DE MÉXICO, 1916
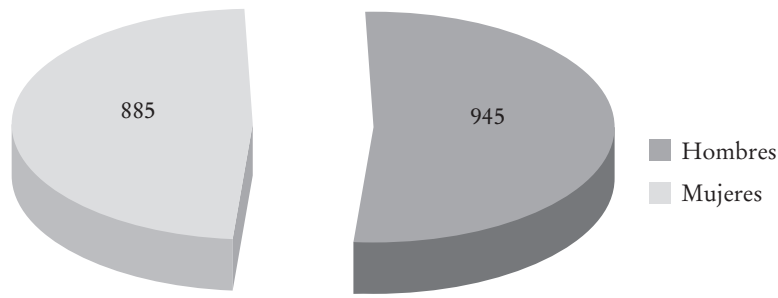

Elaboración propia a partir del Boletín del Consejo Superior de Salubridad, 1, 2, 3, 4, 5 y 6 (ene.-jun. 1916).

El Boletín del Consejo Superior de Salubridad también presenta las estadísticas por grupos de edad. De acuerdo con los rubros considerados en esta publicación, elaboramos la siguiente pirámide de edad (gráfica 6). En la gráfica se aprecia cómo fue aumentando el número de muertos a partir de los 20 años. En suma, podemos aseverar que la epidemia afectó en mayor medida a la población económica y reproductivamente activa, impacto que tendría consecuencias a mediano y largo plazo. Por ejemplo, al morir estos grupos de edad seguramente se afectó más la economía debido a las pérdidas de empleo, las crisis familiares por la muerte del padre o la madre y, más adelante, la caída en el número de bautizos. También en Puebla 25.46 y $25.74 \%$ de las muertes se ubicaron en las edades de 21 a 30 y 31 a 40 años, respectivamente. El 17.10\% fue en los grupos de 41 a 50 años y, en los de 51 a 60 años, fue de $9.20 \% .{ }^{71}$ En la ciudad de México $51 \%$ de los

71 Cuenya, Revolución, p. 127. Es interesante comparar las cifras de muertos por tifo en la ciudad de México y Puebla con las habidas por 
casos se registró en el rango de edad de 30 a 50 años, mientras $23 \%$ en el de 20 a 30 , y en el de mayores de 50 años 17 por ciento.

\section{Gráfica 6}

EPIDEMIA DE TIFO DE 1916.

NÚMERO DE MUERTOS POR GRUPOS DE EDAD

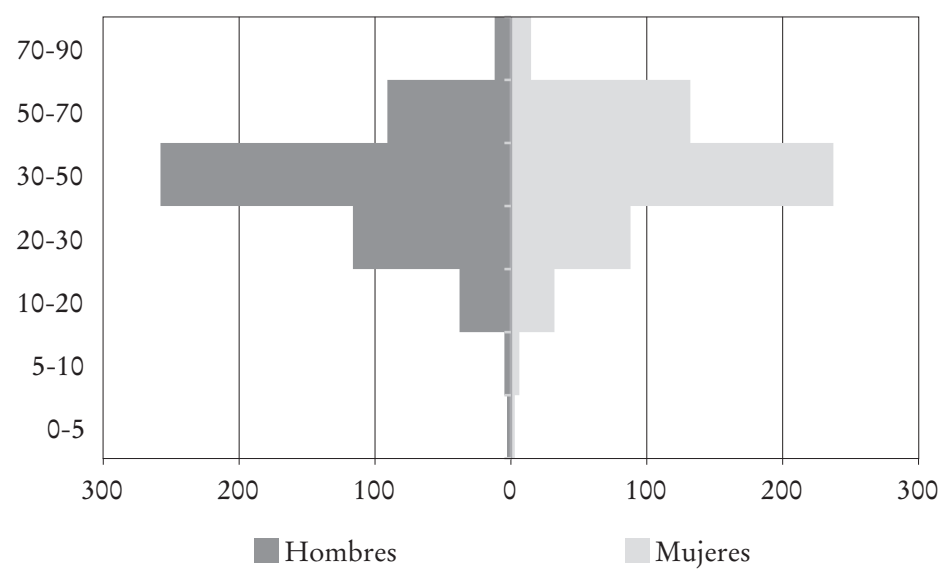

Elaboración propia a partir del Boletín del Consejo Superior de Salubridad, 1, 2, 3, 4, 5 y 6 (ene.-jun. 1916).

En conclusión, puede afirmarse con elementos suficientes que las cifras reales de decesos en la ciudad de México no muestran uniformidad. El total de muertos por el tifo y la guerra se puede confundir debido al gran número de enterra-

influenza en ambas ciudades en 1918. En Puebla murieron por esta epidemia 1828 personas, mientras que en la ciudad de México hubo 2001 decesos. Cuenya, "Reflexiones”, p. 155; Márquez Morfín y Molina del VILlar, "El otoño de 1918”. 
mientos sin registro. Por ejemplo, en septiembre de 1915 el panteón Dolores de Tacubaya, ubicado en una de las municipalidades con mayor número de contagios por tifo, envió un memorándum al jefe de la Sección Quinta de Obras Públicas del Gobierno del Distrito Federal, en el que expuso que el cementerio no disponía de terrenos suficientes para las inhumaciones, por lo que solicitaba aumentar el número de fosas. Se señalaba que el mayor número de cadáveres procedía de los hospitales y que éstos eran remitidos en un estado avanzado de descomposición. La estadística de entierros durante el primer semestre de 1915 arrojaba el siguiente resultado: de 9788 entierros, 5220 adultos y 4515 de párvulos. ${ }^{72}$

Desafortunadamente en el caso del panteón Dolores no se consigna la causa de muerte, aunque estos datos pueden ser un indicio de un importante aumento de la mortalidad, ya fuera por la misma guerra, el tifo u otras enfermedades. De los pocos indicios disponibles tenemos información del panteón San Rafael, de la municipalidad de San Ángel, en donde sí se registraba la causa de muerte. Si bien estos datos no permiten hacer una estadística que cubra un largo periodo, en las actas de defunción consignadas en el panteón se identifica un aumento de muertes por tifo de agosto a diciembre de 1915. En el primer mes no se presentó ni un solo caso,

72 AHDF, Dirección General de Obras Públicas. Panteón Dolores, septiembre de 1915, libro 3510 (1914-1915), exp. 1054. En el último tercio del siglo XviII en Europa emergió con fuerza la idea de la tumba individual. Se consideró que usando una fosa para cada difunto los cementerios apestarían menos. Se trataba de un argumento de higiene y, como señala Philippe Ariés, los muertos se exiliaron de las ciudades. "La muerte perdía su integración en la vida al alejarse de las poblaciones." BeLtrán, Historia de las epidemias, pp. 185-220. El cementerio de Dolores en Tacubaya se encontraba en las afueras de la ciudad y era uno de los de mayor demanda. 
mientras en noviembre y diciembre fallecieron por tifo y fueron sepultados en fosas de segunda y cuarta clase 6 hombres y 6 mujeres de entre 20 y 46 años. Como vimos antes, las edades coinciden con los grupos de edad afectados por la epidemia y que fueron publicados en las estadísticas oficiales. ${ }^{73}$

Un primer sondeo de las actas de defunción del registro civil de la ciudad de México de septiembre a diciembre de 1915 revela el patrón de mortalidad de una sociedad urbana en crisis y con ligeros cambios para completar su transición demográfica. ${ }^{74}$ Esta primera aproximación permite conocer la fuerte presencia de enfermedades infecciosas, como las gastrointestinales, con $47.2 \%$ de un total de 1688 decesos. Y para el caso particular del tifo, con el análisis de 190 actas de defunción de septiembre a diciembre de 1915, identificamos que del total de decesos por tifo y tifo exantemático $66.8 \%$ se ubicaban en los grupos de 25 a 50 años. La reducción de la mortalidad, rasgo de la demografía contemporánea, ocurrió después de esta etapa conflictiva. Otro rasgo que comprobamos en el análisis de las actas de defunción de 1915

\footnotetext{
73 AHDF, Municipalidades. San Ángel. Panteones. Boletas del Registro Civil, c. 4, exp. 19, año de 1915.

${ }^{74} \mathrm{La}$ transición demográfica europea ocurrió en la segunda mitad del siglo xviII, cuando el impacto reiterado de epidemias y crisis demográficas dejan de afectar el crecimiento de la población. La mortalidad infantil disminuyó, la esperanza de vida pasó de entre los 25 y 35 años a los 70-75 años; el número de hijos por mujer descendió de 5 a menos de 2; la natalidad y mortalidad desciende de 30 a $40 \%$ a $10 \%$. Livi Bacci, Historia minima, pp. 197-199. En el caso mexicano, de 1895 a 1910, la esperanza de vida era cercana a los 30 años. Para 1930 la esperanza de vida al nacer era de 37 años. La tasa bruta de mortalidad pasó de 32.9 por 1000 en 1905-1909 a 46.9 por 1000 en 1910-1914, a 48.3 por 1000 en 1915-1919 y a 28.4 por 1000 en 1920-1924. ORdorica y Lezama, "Consecuencias demográficas”, pp. 46-47.
} 
es la elevada mortalidad infantil, prueba que revela la caída en los niveles de vida de la población.

Como se aprecia en la gráfica 7, la mortalidad cobró mayor número de víctimas entre los grupos de 0 a 4 y de 10 a 14 años, sin notables diferencias en cuanto al sexo, aunque en el primer grupo murieron más varones. Cabe indicar que en 1907, 33.8\% del total de la población era menor de 15 años, lo que da cuenta del fuerte impacto de la mortalidad infantil en esos rangos de edad. ${ }^{75}$ Del rango de 20 a 40 años sobresalen los hombres, en tanto que a partir de los 50 años aumenta la mortalidad entre las mujeres. Si se recuerda, este patrón hace pensar en los señalamientos de Ordorica y Lezama, puesto que muestran que uno de los cambios más importantes de la revolución mexicana fue la disminución de la población menor de 10 años. Lo anterior debido al descenso de la natalidad, ${ }^{76}$ así como de la migración y, consideramos que también, a un saldo importante de mortalidad infantil por enfermedades infecciosas. Queda pendiente el análisis de los patrones de nupcialidad y natalidad para evaluar el impacto de la guerra, de la pobreza y de la manifestación de estos padecimientos en las primeras dos décadas del siglo xx. No obstante, un argumento posible es que este primer acercamiento a las repercusiones del tifo y de otras enfermedades es una prueba más de que hasta después de la Revolución

\footnotetext{
${ }^{75}$ En 1907 la población menor de 15 años en el Distrito Federal ascendía a 224 184, de un total. Estadísticas, p. 27.

76 "En 1910 la población de este grupo de edades (menores de 10 años) fue de 4.8 millones de niños, mientras que en 1921 fue de 3.7 millones." Tal diferencia se explica por la mayor omisión del censo de 1921 respecto al de 1910, y por la disminución de la natalidad. ORDORICA y Lezama, "Consecuencias demográficas", p. 41.
} 
el país comenzó su etapa de transición demográfica y crecimiento.

\section{Gráfica 7}

GRUPOS DE EDAD REGISTRADOS EN LAS ACTAS

DE DEFUNCIÓN DE LA CIUDAD DE MÉXICO, SEPTIEMBRE A DICIEMBRE DE 1915

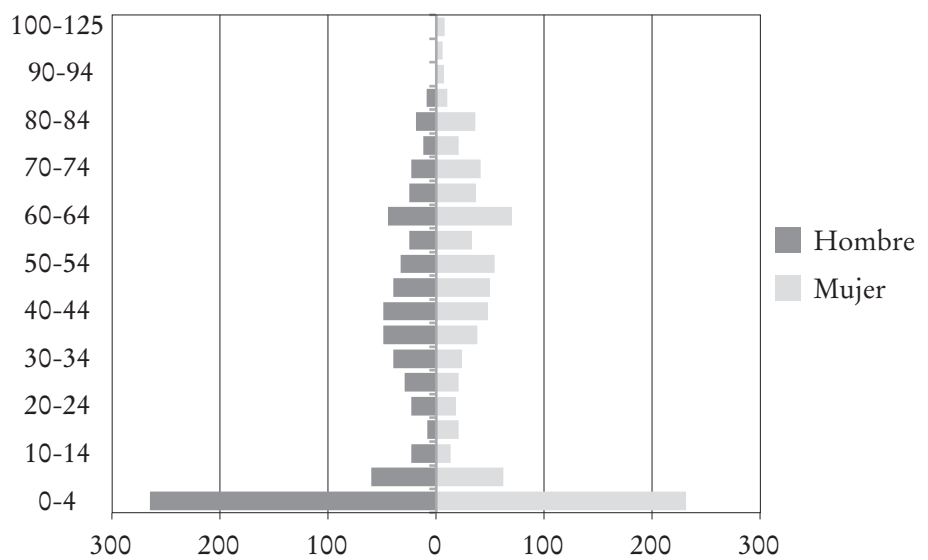

Elaboración propia a partir de las actas de defunción del registro civil de la ciudad de México (www.familysearch.org.search.collection).

En el siguiente apartado nos adentraremos en las características de la campaña sanitaria emprendida por el gobierno constitucionalista en 1915 y 1916. Cabe preguntarse hasta qué punto el número de enfermos empezó a disminuir gracias al éxito de la lucha contra la epidemia, principalmente debido a la política de aislamiento y reclusión de enfermos, así como por las acciones de limpieza e higienización, temas que veremos a continuación. 
“GUERRA CONTRA LA EPIDEMIA": LA CAMPAÑA HIGIENISTA CONTRA LA INSALUBRIDAD, LA RECLUSIÓN DE ENFERMOS Y EL CONTROL SOCIAL

"La guerra contra la epidemia", es decir, la campaña higienista para combatir el contagio del tifo en la ciudad de México, debió considerar el conocimiento médico y etiológico que había en aquel momento. Cabe destacar que, debido a la fuerte prevalencia del tifo murino y epidémico en la ciudad de México, en 1910 la urbe se convirtió en un lugar de experimentación y encuentro científico de médicos mexicanos y extranjeros de la talla de Howard Ricketts, Ángel Gaviño, Charles Nicolle y Joseph Girard que debatían y laboraban en el Instituto Bacteriológico Nacional. ${ }^{77}$ La Revolución afectó el desarrollo científico y los médicos extranjeros dejaron de viajar a la ciudad de México. ${ }^{78}$ Había un acalorado debate sobre el papel del piojo en la transmisión de la enfer-

77 Cuevas, "Ciencia de punta”; Tenorio, "De piojos".

78 Durante estos años hubo descubrimientos importantes, como el del doctor Gaviño, quien en abril de 1911 identificó que los cuyos eran sensibles al microorganismo del tifo exantemático, lo que permitiría después experimentar con monos y de ese modo encontrar una vacuna. Este descubrimiento fue un adelanto significativo para los estudios del médico Nicolle, aunque en aquel tiempo poco importaron estos avances debido a los conflictos militares que sobrevendrían con la caída del gobierno de Díaz. Por desgracia, la inestabilidad política posterior afectó las actividades de Gaviño, ya que con el conflicto entre el gobierno federal y Carranza, el médico fue despedido del Instituto Bacteriológico Nacional, así como varios de sus colaboradores. Gaviño volvió en 1918 y ya en 1919 combatió con éxito una epidemia de peste bubónica que se diseminó desde Tamaulipas hasta Veracruz. Cuevas, "Ciencia de punta”, pp. 71-72, 84-85. 
medad, debido a que por el momento en los experimentos los monos no habían desarrollado el padecimiento. ${ }^{79}$

Hay que recordar que el tifo es un padecimiento provocado por un cocobacilo denominado rickettssia, el cual no puede ser cultivado artificialmente y es incapaz de sobrevivir fuera de las células vivas. De ahí las dificultades para identificar el origen de la enfermedad. El nombre del microorganismo proviene de Howard Ricketts, científico de la Universidad de Chicago, quien murió en 1910 en la ciudad de México, víctima de la enfermedad que estudiaba. $\mathrm{H}$. Ricketts aseguró que el agente transmisor del tifo era el piojo, el cual podía sobrevivir por largo tiempo. ${ }^{80}$

A pesar de los logros alcanzados en el conocimiento de la etiología del tifo, en 1915 y 1916 todavía quedaban dudas sobre las causas que provocaban la enfermedad. El gran dilema era saber cómo hacer frente al brote epidémico. La respuesta estuvo a cargo de los médicos higienistas, cuya experiencia y labor fue adquirida durante el régimen porfirista. Además, en México y en otros países de Latinoamérica, el avance médico de principios del siglo xx se caracterizó por la coexistencia de las teorías pasteurianas y miasmáticas. Los cambios de paradigma no fueron tan mecánicos ni lineales. ${ }^{81}$

\footnotetext{
${ }^{79}$ Cuevas, "Ciencia de punta”, pp. 71-72; también Tenorio, "De piojos", pp. 4-5.

${ }^{80}$ El hallazgo de su descubrimiento apareció publicado unos años después en la prensa. El Imparcial (25 mar. 1911), p. 3.

81 "Las miasmas o el mal olor percibido por el sentido del olfato jugó un papel central en la semiología de la pestilencia. Esta medida originalmente aristotélica subyacía en todas las medidas purificadoras del aire que se sugirieron dentro y fuera de las viviendas." Esta asociación entre mal olor y putrefacción procedía desde el periodo medieval. Desde la peste negra de 1348 y hasta el descubrimiento de la era Pasteur, a fines del siglo XIX,
} 
La teoría miasmática prevalecía en la mentalidad de algunos médicos del Consejo Superior de Salubridad que llevaron a cabo la campaña sanitaria contra la epidemia en 1915 y 1916. En contraposición, otros médicos la cuestionaron y empezaron a tomar en cuenta otros condicionantes sociales, como la pobreza, el hambre y el debilitamiento de la población. ${ }^{82}$ Por su parte, el doctor José Lobato creía que el tifo era resultado del desequilibrio entre las reservas del agua en el suelo y el subsuelo. Para este médico el tifo no era producido ni por una bacteria ni por un virus. ${ }^{83}$

La mayoría de los higienistas de fines del siglo XIX y principios del xx tuvieron una gran influencia de la medicina francesa. Todos ellos fueron defensores de las explicaciones miasmáticas, de la profilaxis del saneamiento y la desinfección. ${ }^{84}$ La convivencia de estas teorías se tradujo en la implementación de variadas medidas de higiene y salubridad. Como demuestra Sandra Caponi para el caso brasileño y argentino, en el pensamiento médico relativo al origen de las epidemias no había una dicotomía, sino que en las teorías epidemiológicas convivían y se complementaban factores

el modelo teórico que guió la actuación de los médicos de formación universitaria permaneció constante. Beltrán, Historia de las epidemias, pp. 194-196.

${ }^{82}$ En las consideraciones de estos médicos pueden encontrarse elementos de la vieja medicina pre pasteuriana, la cual estaba más preocupada por los problemas sociales que por el comportamiento de los microbios, es decir, por combatir la pobreza. Un cambio de paradigma provino después con Pasteur y los nuevos higienistas que lucharon por combatir contra ese universo "amenazador de lo infinitamente pequeño", es decir, los virus, microbios y bacterias. CAPONI, "Miasmas", pp. 155-156.

83 Tenorio, "De piojos", pp. 4-5.

${ }^{84}$ Caponi, "Miasmas", p. 158. 
locales, fuera naturales y sociales, de contagio y de predisposición individual" ${ }^{85}$ En el caso de México encontramos un fenómeno similar, pues de acuerdo con la información de la campaña sanitaria contra el tifo entre 1915 y 1916, las teorías sobre el papel de los piojos en el origen de este padecimiento convivieron con otras explicaciones, como la suciedad, la impureza del aire, los ambiente "pútridos" y la pobreza de ciertos sectores sociales. Así, durante la campaña contra el tifo de 1915 y 1916 se mezclaron explicaciones de miasmas, microbiológicas y sociales.

La pobreza, la guerra y la insalubridad reforzaron las ideas en torno del ambiente insalubre como uno de los causantes del brote epidémico. Los médicos persistían en las ideas acerca de la influencia de los miasmas, ambientes pútridos y malos olores como origen de las epidemias. Por tal circunstancia se recomendaba la ventilación, lavar vestimentas, el drenado de los lagos y de las aguas estancadas, así como la limpieza en el hogar y la ropa de cama. ${ }^{86}$ Estas ideas también convivieron con la teoría microbiológica, en la que se consideraba que los microbios suspendidos en el aire y los vectores (piojos, pulgas, moscas, entre otros) eran causantes de un sinnúmero de enfermedades infecciosas. Durante y después del brote de tifo de 1915 y 1916 en la prensa se editaron artículos y propaganda en torno al papel que desempeñaban los piojos en el contagio del tifo. ${ }^{87}$

85 Caponi, “Miasmas”, p. 159.

86 Tenorio, "De piojos", p. 9.

87 En relación con la teoría microbiana y su difusión por medio de la prensa, véase Agostoni, "Los infinitamente pequeños"; "Popular Health". Sobre las ideas acerca de la enfermedad e instituciones públicas en México, Vera Bolaños, "Ideas sobre la enfermedad". 
La campaña higienista contra la epidemia de tifo de 1915 y 1916 debe comprenderse en este contexto de la guerra, crisis política, pobreza y hambre. De algún modo, consideramos que el manejo de la emergencia alimenticia y sanitaria fue otro coadyuvante para fortalecer al gobierno de Carranza en un momento crítico, porque aún libraba batallas contra otras fuerzas políticas del país y todavía no había logrado el reconocimiento nacional e internacional, principalmente de Estados Unidos. A continuación nos adentraremos en las actividades del Consejo Superior de Salubridad al mando del gobierno constitucionalista, sobre todo en la actuación de José María Rodríguez, hombre cercano a Venustiano Carranza. En las iniciativas promulgadas por este médico coahuilense notamos la confección de una campaña muy enérgica en términos de higiene y control social.

La población de la ciudad de México se enfrentó a un gran problema por parte de sus autoridades. No se pudo controlar o prevenir el brote violento de tifo debido a la inestabilidad política a consecuencia de los constantes cambios de gobierno. La principal crisis en materia de higiene y salubridad ocurrió cuando Eduardo Liceaga presentó su renuncia a la presidencia del Consejo Superior de Salubridad, 13 días después del golpe militar de Victoriano Huerta. Sin embargo, permaneció en el puesto hasta agosto de 1914, cuando fue sustituido por el médico Ramón Macías. Liceaga salió de la presidencia del Consejo precisamente cuando el hambre, la guerra y las enfermedades empezaron a agravarse. ${ }^{88}$

${ }^{88}$ Uno de sus más importantes biógrafos, Francisco Fernández del Castillo, señala que Eduardo Liceaga (1839-1922) fue un modelo de médico, caballero y hombre de estado. Fue un hombre cercano a Porfirio Díaz y colaboró arduamente para transformar las condiciones de salubridad de 
Cabe señalar que durante el breve pero intenso gobierno de Huerta nueve secretarías tuvieron 32 titulares. En 1914 el gabinete era nulo, a pesar de que sus miembros habían recibido rangos y uniformes militares. ${ }^{89}$

José María Rodríguez tomó la dirección del Consejo Superior de Salubridad en agosto de 1914. Sin embargo, el traslado de poderes a Veracruz impidió que entrara en funciones en la ciudad de México. Una de sus primeras acciones fue enviar a Xalapa el Instituto Bacteriológico Nacional, con el fin de producir allí mismo la vacuna antivariolosa, debido a una epidemia de viruela que estaba afectando al estado. Ya señalamos que, mientras el Consejo Superior de Salubridad estaba en Veracruz, en la ciudad de México la dirección de esta institución fue asumida por el doctor Macías y varios delegados. A principios de 1915, en las sesiones del Consejo se hacía referencia a la situación que de algún modo generó un vacío en la administración de sanidad debido a la guerra y falta de recursos. Al finalizar la sesión se señalaba que "[...] juzgados, escuelas, institutos y Consejo de Salubridad quedará suspendido". ${ }^{90}$

Además de la falta de dirección y coordinación en materia sanitaria, la disputa revolucionaria empeoró la situación económica del país, pues cada facción emitió su propia moneda,

México. Fue diputado federal, profesor y director de la Escuela Nacional de Medicina. Viajo a París y conoció a Luis Pasteur. Introdujo la vacuna contra la rabia en México e hizo investigaciones valiosas sobre el tifo y la fiebre amarilla. Véase "Eduardo Liceaga", disponible en línea (http:// www.auamex/medicina/duardo.html), CArrillo, "Eduardo Liceaga", pp. 371-375; "Surgimiento", pp. 24-25.

${ }_{89}$ KNight, La Revolución, vol. II, pp. 638-639.

90 AHSSA, Salubridad Pública, Presidencia. "Actas de la sesión del Consejo Superior de Salubridad”, sesión celebrada el 1 de febrero de 1915. 
provocando inflación y caos. ${ }^{91} \mathrm{La}$ Convención tomó el control de la ciudad desde noviembre de 1914 y hasta enero de 1915..$^{92}$ Aunque los miembros de la Convención formaron un Comité de Salud Pública, es evidente que estos cambios frenaron la posibilidad de dar continuidad a la campaña sanitaria, lo que como ya vimos se tradujo también en la imposibilidad de disponer de una estadística puntual y serial de enfermos y muertos a consecuencia del tifo y de otras enfermedades infecciosas.

La salida de José María Rodríguez significó que gran número de servicios públicos quedaran suspendidos. Se temía que en unos días la capital volviera a ser tomada por los zapatistas, hecho que ocurrió el 11 de marzo de 1915. José María Rodríguez, ante sesión con los miembros del Consejo, finalizó su intervención con una sentencia para la capital:

${ }^{91}$ El gobierno tuvo que cubrir todos sus gastos con las diversas clases de billetes de que disponía, situación que se agravó al tener que entregar decenalmente de 100000 a 200000 pesos al Ejército Libertador del Sur y socorrer a las multitudes hambrientas. Los precios de los artículos de primera necesidad subieron exageradamente: $2400 \%$ el maíz, 2200 el frijol, 1420 el arroz, 940 el azúcar y 900 la harina. Los socorros no fueron suficientes y se desató una ola de asaltos y pillaje, además de motines sangrientos. Por otra parte, el gobierno de la Convención sólo logró recaudar 234000 pesos en moneda metálica, que se vio obligado a entregar a los bancos para recoger 400000 pesos villistas y evitar la bancarrota. UlloA, "La lucha armada", p. 799.

${ }^{92}$ Las fuerzas de la Convención, después de la ruptura con Carranza, avanzaron hacia las inmediaciones de la capital del país a fines de noviembre de 1914. Para entonces eran casi dueñas de la mayor parte del país. Estas fuerzas, provenientes de Aguascalientes, estaban compuestas principalmente por la División del Norte. En tanto el Ejército Libertador del Sur, que aún no se había adherido a la Convención, se encontraba en la periferia de la ciudad, éstos comenzaron a ocuparla en los últimos días de noviembre y primeros días de diciembre. Ávila, "La ciudad de México", p. 6. 
“[...] todo quedará suspendido, porque en primer lugar no hay dinero suficiente, y en segundo porque como va a quedar la población de México sujeta a todos los vaivenes de la guerra, por haber dejado de ser la Capital de la República, así es que sufrirá esta población lo mismo que cualquiera otra". ${ }^{93}$

Y efectivamente, la ciudad sufrió el hambre y las enfermedades, pero padecería más la falta de una respuesta coordinada por parte de las autoridades para hacer frente a la emergencia sanitaria y alimenticia. En la sesión de febrero José María Rodríguez se despidió y dio las gracias a los funcionarios por su servicio, pero advertía que se trataba de una suspensión temporal. Cabe decir que de la ocupación constitucionalista de agosto de 1914 a su recuperación definitiva un año después, la capital fue desalojada y ocupada seis veces por carrancistas y convencionistas. En este tiempo ninguna de las fuerzas estuvo dispuesta a sacrificar o comprometer recursos en la administración de la urbe. El objeto era su ocupación militar. Los revolucionarios impusieron la ley marcial, cerraron cantinas, fusilaron a varios saqueadores y exhibieron cadáveres a modo de advertencia. ${ }^{94} \mathrm{Al}$ respecto, Knight señala que Carranza y Obregón sentían cierto desprecio hacia la ciudad de México porque consideraban que era conservadora y no había padecido los estragos de la guerra y las confrontaciones militares. Ambos jefes revolucionarios estaban influidos por sentimientos de un viejo federalismo norteño, además de que consideraban que ahí

\footnotetext{
93 "Acta de la sesión extraordinaria efectuada con motivo de haberse presentado el doctor José María Rodríguez a recibir el Consejo Superior de Salubridad, el 1ํ de febrero de 1915." AHSSA, Salubridad. Presidencia, Actas de Sesión, año de 1915.

${ }^{94}$ Rodríguez Kuri, Historia del desasosiego, pp. 144-145.
} 
había beligerantes inexpertos. ${ }^{95}$ Quizá todo esto se manifestó en la desatención de múltiples problemas que padecía la capital, como fue el creciente deterioro en los servicios sanitarios.

Estos acontecimientos explican en gran medida vacíos de información en torno del comportamiento de la epidemia en el primer semestre de 1915, así como de las medidas adoptadas para hacerle frente. Las tropas zapatistas regresaron y encontraron una difícil situación en la ciudad. Las comunicaciones estaban cortadas, las líneas de ferrocarril dañadas, no había agua potable, las tuberías estaban averiadas por los enfrentamientos, el servicio de tranvías se había suspendido en virtud de que varios de sus empleados se habían ido con Obregón. Faltaba la electricidad, el combustible; la vigilancia era casi nula. Muchos comercios habían cerrado y continuaban la escasez y carestía de alimentos. ${ }^{96}$ Todos estos factores fueron deteriorando las condiciones de vida de los capitalinos, principalmente en materia de sanidad y nutrición. No era de extrañar que meses después el tifo hiciera su aparición, pero con mayor virulencia.

A fines de 1915 el panorama era desolador. La prensa, principalmente El Demócrata, publicó diversas noticias sobre el curso de la guerra y de la epidemia. En los últimos días de diciembre de 1915, en primera plana se publicó el siguiente encabezado: "El tifo toma proporciones alarmantes". Hay artículos y narraciones sobre el terror y pánico ante el tifo. El encabezado era ampliado con la siguiente narración: “ $\mathrm{Da}$ pena ver cómo desaparecen de la noche a la mañana seres buenos y útiles, asesinados alevosa y prematuramente por la

\footnotetext{
95 Knight, La Revolución mexicana, vol. II, p. 745.

96 Ávila, “La ciudad de México”, p. 13.
} 
horrible epidemia. Se culpa a los zapatistas del hambre y del tifo". ${ }^{97}$

La epidemia y su diseminación generaron un ambiente de linchamiento hacia las distintas facciones enfrentadas. Como ya vimos, Orvañanos, por su parte, atribuyó al ejército constitucionalista del haber diseminado el contagio. Durante el gobierno de la Convención, ${ }^{98}$ el doctor Macías, quien en ese momento estaba al frente del Consejo, culpó del contagio del tifo y de otras enfermedades infecciosas a los numerosos ejércitos instalados en los alrededores de la ciudad. ${ }^{99}$

Como vimos líneas atrás, en estos momentos complicados para la ciudad destacó la participación del doctor Domingo Orvañanos, encumbrado científico e higienista porfirista. El hombre tenía una larga experiencia en materia de salud pública, además de haber colaborado con Eduardo Liceaga. Durante los años de 1915 y 1916 vemos su intervención en las sesiones del Consejo Superior de Salubridad, al frente de la campaña sanitaria y como responsable de la publicación de las estadísticas de enfermos y muertos. A principios

\footnotetext{
97 El Demócrata (28 dic. 1915), p. 1.

98 El 10 de marzo de 1915 Obregón abandonó la capital y el 11 entraron los zapatistas. En la sesión del día 16 se informó por sendos oficios de las secretarías de Hacienda y Gobernación de la Convención, que el ayuntamiento manejaría otra vez la oficina de ramos municipales, lo cual era vital para que esta institución contara con dinero. Para el 22 de marzo en sesión de cabildo se acordó que el ayuntamiento manejara otra vez el ramo de obras públicas. Rodríguez Kuri, Historia del desasosiego, pp. 109-110.

99 AHSSA, Salubridad Pública, Presidencia. "Actas de la sesión del Consejo Superior de Salubridad", sesión celebrada el 20 de marzo de 1915. Presidencia del Dr. Macías; sesión celebrada el 30 de octubre de 1915, siendo presidente A. de Luca.
} 
de 1915 Orvañanos ya había recomendado algunas medidas generales de higiene y desinfección en las escuelas. ${ }^{100}$

Cabe señalar que el agravamiento y la diseminación del tifo en los barrios y arrabales citadinos fueron temas que se empezaron a examinar a principios de 1915, debido a la incertidumbre que había sobre el alcance y eficacia de las campañas sanitarias. Este debate se materializó en la dirección de la política sanitaria implementada en ese momento. En las sesiones del Consejo Superior de Salubridad algunos médicos higienistas señalaban que la materia orgánica en descomposición y el agua estancada eran factores en la aparición del tifo, ideas que prevalecían en la mentalidad de muchos médicos e higienistas de la época, en la que vemos -como ya referimos- la conjunción de teorías miasmáticas y microbiológicas. ${ }^{101}$ De tal suerte que se ordenó rellenar zanjas, y echar petróleo en las aguas estancadas, como ocurría en las campañas contra la fiebre amarilla. Se consideraba que tales medidas darían mejores resultados que "los simples recursos de aislamiento y desinfección”. Se advertía de brotes en algunos cuarteles de la ciudad, como el 5 y el 8. En este últi-

100 “Acta de la sesión del 13 de enero de 1915.” AHSSA, Salubridad. Presidencia, Actas de Sesión, año de 1915.

101 Para los primeros higienistas ese miedo al contagio se confundía con la propagación de los miasmas y del aire mefítico. Al respecto, Caponi hace referencia a Wilde (1883), quien señalaba que "cuanto menos aseada era una ciudad, cuanto más depósitos de materias putrescibles contuviera, tanto menos higiénico sería el suelo y, por lo tanto, menos puro el aire, que se encontrará cargado de gases y de vapores dañinos", CAPONI, "Miasmas", p. 171. Una situación similar ocurrió con los higienistas mexicanos de principios del siglo xx, en virtud de que aguas estancadas, estiércol, depósitos de cadáveres, polvos y basuras eran considerados focos de contagio y de diseminación de múltiples enfermedades y epidemias. Agostoni, "Los infinitamente pequeños"; "Popular Health". 
mo había gran cantidad de caballos muertos, principalmente en los alrededores de la Condesa. La causa de la mortalidad de animales era la falta de pasturas. Los caballos de sitios eran alimentados con zacate y trabajaban lo doble por falta de trenes. Los animales eran arrojados a los basureros. Otro problema sanitario era la acumulación de tropas en las municipalidades. ${ }^{102}$

A partir de agosto de 1915, la campaña higienista empezó a adquirir otros tintes que vemos materializados en la reclusión forzosa de enfermos de tifo. Fue precisamente entre octubre de 1915 y octubre del año siguiente cuando comenzó a hacerse el traslado de enfermos de tifo a los hospitales General y Tlalpan. Durante 1915 y 1916 hombres y mujeres afectados por otras enfermedades infecciosas también fueron remitidos a dichos hospitales. Si bien se presentaron otros padecimientos, como la viruela y la escarlatina, el tifo superó por mucho a la suma total de las afecciones, con $95 \%$ de casos detectados. La viruela y la escarlatina, que en años anteriores reportaron un mayor número de casos, tuvieron menor presencia. De octubre a diciembre de 1915 se remitieron 2593 enfermos al Hospital General. Al parecer, en enero la capacidad de dicho nosocomio se vio limitada debido al gran número de ingresos y su lugar fue ocupado por el Hospital de Tlalpan hasta mayo de 1916, cuando de nueva cuenta el Hospital General volvió a recibir enfermos. En la estadística de enfermos también tenemos registrados otros hospitales, como el Hospital Juárez, el Hospital Militar, el

102 AHSSA, Salubridad Pública, Presidencia. "Actas de la sesión del Consejo Superior de Salubridad”, sesión celebrada el 20 de enero de 1915; sesión celebrada el 24 de marzo de 1915. 
Hospital Inglés y el lazareto San Joaquín, pero el número de enfermos en esos nosocomios fue insignificante. En un principio el traslado de enfermos a los hospitales se hizo en 6 carros y 10 troncos de caballos o mulas. ${ }^{103}$ En un solo año fueron remitidos un total de 11197 individuos a estos hospitales, cifra que nos habla de la enérgica campaña que se llevó a cabo para aislar y recluir a los enfermos (gráfica 8).

\section{Gráfica 8}

TOTAL DE ENFERMOS DE TIFO TRASLADADOS

A LOS HOSPITALES DE LA CIUDAD DE MÉXICO, 1915-1916

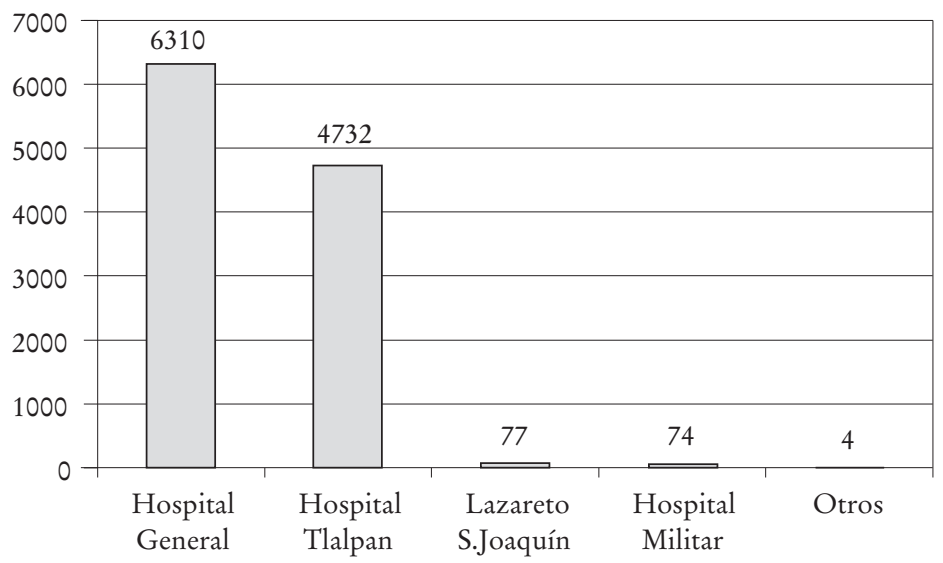

Elaboración propia a partir del "Libro de traslados de enfermos infecto contagiosos. Contiene nombres, enfermedades, domicilios, procedencia, destinos, observaciones, la mayor incidencia es de tifo, octubre de 1915 a octubre de 1916”. AHSSA, Salubridad Pública. Epidemiología, c. 11, exps. 1 y 2.

103 AHSSA, Salubridad Pública, Presidencia. "Actas de la sesión del Consejo Superior de Salubridad”, sesión celebrada el 2 de enero de 1915. 
En esta etapa de gran incertidumbre social y de emergencia sanitaria los hospitales de la ciudad fueron lugares de reclusión y aislamiento de enfermos, lo que quizá hizo disminuir un contagio mayor. Pero, sobre todo, esta política de reclusión y aislamiento de enfermos contagiosos revela un modelo de medicina social y urbana caracterizada por Foucault, en la que el poder político de la medicina consistía en aislar e individualizar a los enfermos, vigilarlos, verificar su estado de salud, comprobar si habían muerto o no. Los hospitales y toda su estructura de salud fungieron como "una máquina de guerra y vigilancia" para controlar la salud, la curación y el retorno de los individuos a la vida productiva, laboral. El objeto primordial era contabilizar a los enfermos, llevar estadísticas de los que se podían recuperar, "dejar morir a los que no tenían otra opción y devolverles pronto las facultades corporales a los más aptos para continuar sirviendo a la sociedad en las transacciones de la vida laboral". ${ }^{104}$ Todas estas funciones se pueden visualizar en la iniciativa de Rodríguez de trasladar a los hospitales a los enfermos de tifo y de otras enfermedades infecciosas durante 1915 y 1916. Del mismo modo, esta política de aislamiento y reclusión de enfermos podemos analizarla bajo el enfoque de Foucault y de otros autores respecto al análisis del control social hacia las clases populares. ${ }^{105}$

104 Foucault, La vida de los hombres, pp. 62, 70-78.
105 Para Foucault y otros historiadores, como Alain Corbin y Susan
Conner, el control social es un producto histórico del conflicto y como
tal deben analizarse su evolución y transformaciones. Se pueden encon-
trar varios ejemplos, tales como la reglamentación de la prostitución, la
inspección de las prácticas cotidianas y la vigilancia de la sociabilidad, lo
que permitió a la burguesía cierta legitimidad. Foucault y Corbin revelan 
También es cierto que desde el siglo xix los hospitales no sólo fueron lugares de aislamiento y reclusión de enfermos, sino centros de estudio e investigación de diversas enfermedades, como el tifo. El Hospital General, el Hospital Juárez y el Hospital Americano, así como los Institutos Patológicos y el Bacteriológico Nacional comandaron las investigaciones sobre el tifo entre 1900 y 1930. Estos nosocomios destacaron por haber sido sitios de investigación de médicos y científicos, como José Terrés, Manuel Otero, Gerardo Varela, Joseph Girard y Hermann Mooser. ${ }^{106}$ Sin duda, citando de nuevo a Foucault, la lección de los hospitales se relacionaba también con la enseñanza de la clínica: "Las enfermedades y la muerte ofrecen grandes lecciones en los hospitales", son espacios que permiten escribir la historia de los males, el arte de observar y tratar las enfermedades. ${ }^{107} \mathrm{Y}$ esta función es precisamente la que observamos en estos años de brotes epidémicos, a pesar de las limitaciones presupuestales y de la inestabilidad política.

que en el caso europeo el control y supervisión de las costumbres surgió en los siglos XVII y XIX con el auge de la centralización y el surgimiento de la burguesía para crear cierta legitimidad "alrededor de un nuevo ente", el cual podía actuar de manera arbitraria combinando el arresto perentorio con el castigo de "las denominada faltas simples, asociadas con la supervisión del cuerpo, los hábitos, la actividad lúdica y las tradiciones populares”. En 1915 y 1916 en la ciudad de México la situación de emergencia sanitaria, aunada a la crisis política, llevó a confeccionar una política higienista de control y estricta supervisión de individuos, hogares y lugares públicos. Sobre un balance historiográfico y metodológico del control social, véase Marín Hernández, "El control social”, pp. 1-4. 106 Ángel Gaviño, Miguel Otero y Hermann Mooser identificaron las características del tifus murino o "tifus mexicano", cuyo medio de contagio era un artrópodo transmitido por la pulga de la rata. Tenorio, "De piojos", pp. 5-11.

107 Foucault, El nacimiento, p. 97. 
El libro de registro del traslado de enfermos de tifo y de otras enfermedades infecciosas también nos permite identificar los cuarteles, barrios y colonias con mayor número de tifosos, lo que a su vez permite relacionar estas cifras con las condiciones de pobreza e insalubridad. En el plano 1 se aprecia que los cuartes I, II, III, V y VI reportaron el mayor número de enfermos remitidos a los hospitales de la ciudad de México. No disponemos de cifras o de censos de fecha cercana al brote epidémico, cuyos totales de población permitan calcular con exactitud las tasas de mortalidad o de incidencia de tifo. El dato más próximo es el censo de 1895, en el cual aparecen los totales de habitantes en los ocho cuarteles de la ciudad de México. ${ }^{108} \mathrm{Al}$ relacionar ambas cifras identificamos que los cuarteles I, II, V y VIII reportaron una mayor prevalencia o proporción de enfermos; principalmente destaca el último, que era uno de los más insalubres y pobres de la ciudad ${ }^{109}$ (cuadro 3). Si comparamos el impacto del tifo de 1915-1916 en la ciudad de México con el estudio de Márquez Morfín sobre la epidemia de tifo de 1813 y el cólera de 1833 , podemos detectar una mortalidad diferencial, en virtud de que la población más afectada por estos tres sucesos fue aquella cuyas condiciones socioeconómicas la orillaban a vivir en lugares más infectos. Los pobres de los arrabales vivían en viviendas que carecían de los servicios sanitarios más necesarios, agua y drenaje. ${ }^{110}$

108 Esta información apareció publicada en el Diario Oficial y fue reeditada por el periódico El Siglo XIX (30 oct. 1895). La nota aparece a su vez en Gortari y Hernández, Memorias y encuentros, vol. iII, p. 282.

109 Beltrán Rabadán, “La epidemia de tifo”, p. 163.

110 Márquez Morfín, La desigualdad ante la muerte, pp. 20-21. 


\section{Plano 1 \\ PROCEDENCIA Y NÚMERO DE ENFERMOS DE TIFO \\ QUE FUERON TRASLADADOS A LOS HOSPITALES DE LA CIUDAD DE MÉXICO, DE OCTUBRE DE 1915 A OCTUBRE DE 1916}

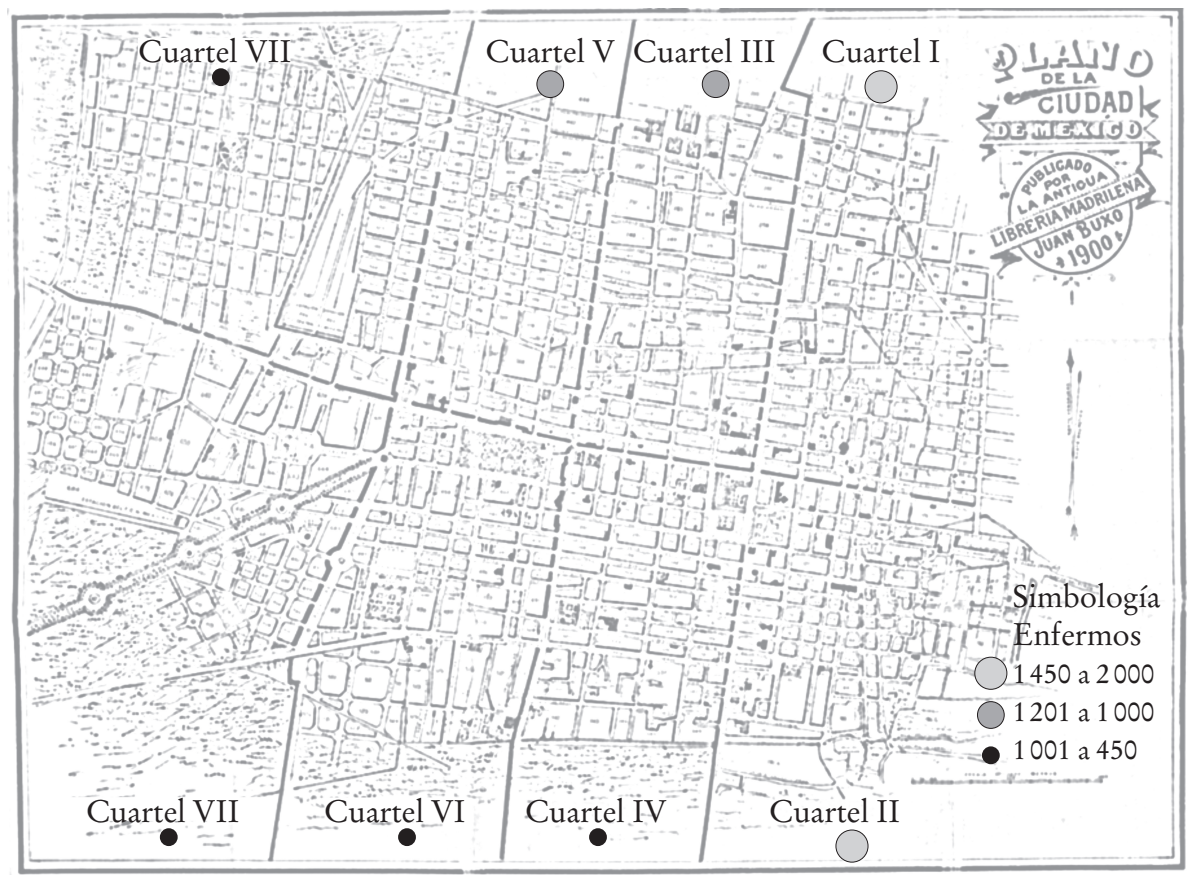

Elaboración propia a partir del "Libro de traslados de enfermos infecto contagiosos. Contiene nombres, enfermedades, domicilios, procedencia, destinos, observaciones, la mayor incidencia es de tifo, octubre de 1915 a octubre de 1915”, AHSSA, Salubridad Pública, Epidemiología, c. 11 , exps. 1 y 2. 


\section{Cuadro 3}

PROPORCIÓN DE ENFERMOS DE TIFO EN 1915 Y 1916

EN RELACIÓN CON EL TOTAL DE HABITANTES, CIUDAD DE MÉXICO

\begin{tabular}{lccc}
\hline Número de cuartel & $\begin{array}{c}\text { Total de } \\
\text { babitantes en } 1895\end{array}$ & $\begin{array}{c}\text { Total } \\
\text { de enfermos }\end{array}$ & $\begin{array}{c}\text { Tasa de inci- } \\
\text { dencia* }\end{array}$ \\
\hline Cuartel I & 44194 & 1333 & 3.0 \\
Cuartel II & 69203 & 1446 & 2.0 \\
Cuartel III & 69338 & 1238 & 1.7 \\
Cuartel IV & 46028 & 799 & 1.7 \\
Cuartel V & 43623 & 1250 & 2.8 \\
Cuartel VI & 38205 & 893 & 2.3 \\
Cuartel VII & 21720 & 554 & 2.5 \\
Cuartel VIII & 12063 & 447 & 3.7 \\
\hline
\end{tabular}

Fuentes: Gortari y Hernández, Memorias y encuentros, vol. iII, p. 282; AHSSA, "Libro de traslados de enfermos infecto-contagiosos. Contiene nombres, enfermedades, domicilios, procedencia, destinos, observaciones, la mayor incidencia es de tifo, octubre de 1915 a octubre de 1916", Salubridad Pública. Epidemiología, c. 11, exps. 1 y 2.

"La fórmula es: número de casos en un momento dado $\times 100$ total de población

En 1915 y 1916 los barrios más sucios y en donde había gran hacinamiento se ubicaban en las colonias La Bolsa, Valle Gómez, Tepito, Manzanares y La Merced, localizadas en los primeros dos cuarteles. Del mismo modo, en los barrios de Guerrero, Morelos, Santa Julia, Indianilla, Díaz de León, Mesa y Rastro vivían hombres y mujeres "casi desnudos al lado de perros y cerdos, con calles, plazas y arrabales” en donde predominaban la humedad, la suciedad, desechos e insectos. En estos lugares se carecía de alumbrado, pavimen- 
tación, desagüe, letrinas, acequias, policía, y había gran cantidad de basura. ${ }^{111} \mathrm{Al}$ respecto, Domingo Orvañanos señalaba que la mortalidad por el tifo aumentaba en relación con la densidad de población. Por ello se comprobó que los coeficientes más elevados de mortalidad ocurrieron en los cuarteles II y VIII, los más poblados y en donde existía mayor aglomeración. ${ }^{112}$ Además de incluir al cuartel número I, estos mismos coeficientes muestran similitudes con las tasas brutas de mortalidad calculadas al relacionar el número de muertos con el total de población del censo de 1895 (cuadro 4). En cuanto a otras características de estos lugares, el mismo doctor Valenzuela advirtió sobre varias casas de vecindad en los cuarteles I y II, las cuales eran "una amenaza constante para la salubridad pública”, debido al gran número de casos de tifo exantemático. Para combatir la enfermedad lo mejor era el baño diario de "la gente sucia y aglomerada", medida que como veremos más adelante se generalizó durante los años de la epidemia. ${ }^{113}$

111 En Beltrán Rabadán, “La epidemia”, pp. 37-38, 88.

112 En 1895 el coeficiente nacional de mortalidad fue de 31.0; el del D. F. de 43.0, pero de 65.0 el del cuartel II y de 54.4 el del VIII, en González Navarro, Población y sociedad, p. 143.

113 Valenzuela, "Medidas profilácticas”, p. 265; Beltrán Rabadán, “La epidemia”, pp. 94-96. Al respecto, Carrillo señala que los descubrimientos de Pasteur y Koch mostraron que el enfermo era capaz de transmitir enfermedades, por lo que los higienistas lo responsabilizaron de ello. Lo anterior influyó en los enfoques médicos y programas sanitarios, como fue el caso de medidas estrictas y "el control de la higiene de los cuerpos". Carrillo, “Del miedo", p. 120. 


\section{Cuadro 4}

NÚMERO DE MUERTOS POR LA EPIDEMIA DE TIFO, ENERO-DICIEMBRE DE 1916. TASAS BRUTAS DE MORTALIDAD

\begin{tabular}{lcc}
\hline Numero de cuartel & Total de muertos & TBM* \\
\hline Cuartel I & 277 & 6.2 \\
Cuartel II & 295 & 4.2 \\
Cuartel III & 213 & 3.0 \\
Cuartel IV & 101 & 2.1 \\
Cuartel V & 170 & 3.8 \\
Cuartel VI & 586 & 15.3 \\
Cuartel VII & 75 & 3.4 \\
Cuartel VIII & 113 & 9.3 \\
\hline
\end{tabular}

Fuentes: Gortari y Hernández, Memorias y encuentros, vol. iII, p. 282; Boletin del Consejo Superior de Salubridad, enero-diciembre de 1916, números, 1 al 12.

* Tasa bruta de mortalidad. Número de muertos/total de la población $\times$ 1000.

Aquí sorprende el cuartel número VI, en virtud de que muestra la tasa bruta de mortalidad más alta. Cabe decir que ahí se encontraba la colonia Doctores, la cual estaba inconclusa por falta de urbanización y carecía de las instalaciones sanitarias reglamentarias. La población más pobre residía en el perímetro ubicado entre la calle Doctor Río de la Loza, el Hospital General y las calzadas Niño Perdido y La Piedad, ${ }^{114}$ calles que fueron mencionadas un sinnúmero de veces en el libro del traslado de enfermos infecto contagiosos. Como se aprecia en el cuadro 3, el cuartel VI ocupó el quinto lugar en cuanto al número de enfermos de tifo.

114 González Navarro, Población y sociedad, pp. 145-146. 
Entre las colonias más insalubres de la ciudad figuraba La Bolsa, la cual constantemente salía a relucir en los informes médicos y en la prensa. Como se ha señalado, esta colonia se ubicaba en el cuartel I. Su situación preocupó a las autoridades sanitarias, por lo que consideraron urgente empedrar las calles, introducir agua potable, limpiar las atarjeas y quitar los muladares. En dicha demarcación había hornos de ladrillos e industrias nocivas. ${ }^{115}$ En la prensa se denunciaron en más de una ocasión las deplorables condiciones de insalubridad de la colonia La Bolsa, en donde había gran número de terrenos sin bardar y falta de aseo. Algunas habitaciones no tenían puertas y se habían convertido en excusados. Se solicitaba la actuación de los agentes de policía para presionar a que los dueños de las accesorias no tiraran agua sucia ni desperdicios. Los habitantes podían seguir trabajando y hacer los desagües en los pozos de visita. ${ }^{116}$

En diciembre de 1915, cuando el tifo comenzó a diseminarse con severidad, el Consejo Superior de Salubridad envió a la colonia La Bolsa una cuadrilla de "recogedores de basura y materias dañosas". En su informe respectivo, los agentes notificaron que el lugar era una verdadera amenaza contra la higiene: "muchos de los predios están sin bardar y que sólo viéndolos se da uno cuenta el sujeto de su valor morbosos, no recibieron el cabal aseo, se observan en ellos no sólo focos infecciosos, sino también que en algunas habitaciones faltan puertas que se han convertido en excusados". Este organismo advertía que la policía y las cuadrillas de basura de la

115 González Navarro, Población y sociedad, pp. 143-145.

116 El Demócrata (29 dic. 1915), p. 3. 
Dirección de Obras Públicas no estaban cumpliendo con sus obligaciones. ${ }^{117}$

Además de las denuncias de la insalubridad en varias colonias y barrios de la ciudad, la campaña contra la epidemia se dirigió a desinfectar los lugares y viviendas en donde se reportaban los enfermos. Para ello se nombraron agentes sanitarios, quienes se distribuyeron en los ocho cuarteles de la ciudad y levantaban las infracciones por contravenir normas contra la higiene. Estos individuos recorrieron calles, mercados y plazas para reportar animales muertos, viviendas en mal estado y tiraderos de basura. ${ }^{118}$

A fines de 1915, cuando la epidemia cundía con gran severidad, José María Rodríguez expresó su inconformidad en una de las sesiones del Consejo porque las cuadrillas sanitarias no se habían empleado a fondo en el combate de la epidemia. Acababa de recorrer la colonia La Bolsa, en donde la mayor parte de sus calles no se habían barrido en varios meses y había "verdaderos muladares, zanjas en donde los vecinos arrojaban aguas sucias y materias fecales". Por lo anterior ordenó el envío de 400 hombres de las cuadrillas de limpieza para el aseo de las calles y quema de basuras con petróleo. Ahí mismo se llevarían a cabo inspecciones casa por casa, principalmente en aquellas en donde se reportaron enfermos de tifo. ${ }^{119}$ Como ocurrió en los casos brasileño y

\footnotetext{
117 El Demócrata (29 dic. 1915), p. 3.

118 Beltrán Rabadán, “La epidemia”, pp. 172-173.

119 AHSSA, "Actas del Consejo Superior de Salubridad". Sesión celebrada el 4 de diciembre de 1915; "Oficio del Consejo Superior de Salubridad, 13 de diciembre de 1915, p. 1", Medidas dictadas por el Consejo Superior de Salubridad para reforzar la campaña contra el tifo, c. 10, exp. 3, 1915-1916.
} 
argentino analizados por Caponi, también en México estos médicos e higienistas se consagraron a identificar las viviendas o vecindades insalubres y detectar las "islas de insalubridad” en donde vivían las personas hacinadas, quizá pertenecientes a sectores populares. ${ }^{120}$

Para llevar a cabo las desinfecciones se utilizaron diversas sustancias, como ácido sulfuroso, creolina líquida, bolas de naftalina, sulfato de cobre, formol, azufre, polvo de crisantema, insecticidas (Chloro-Naptholeum), alcohol metílico, ácido clorhídrico, peróxido de manganeso, bicloruro de mercurio y alcohol, entre otras. Estas sustancias eran utilizadas para desinfectar escuelas, cines, templos, hospitales y las viviendas en donde se reportaron casos de tifo. De estos productos, por ejemplo, el polvo de crisantema se utilizó para "la destrucción de los piojos". Del mismo modo, se empezaron a promocionar fumigadores estadounidenses, que usaban formalheído, el cual era considerado un poderoso desinfectante, representado por la Central City Chemical Co. ${ }^{121}$

120 "Los controles sanitarios referidos a la vivienda popular y la figura del visitador ponen en evidencia una complementariedad entre las diferentes estrategias sanitarias adoptadas por los higienistas clásicos y el nuevo higienismo, heredero de la llamada Revolución Pasteuriana.” En Brasil y Argentina de fines del XIX y principios del xx, "estas estrategias sanitarias relativas a la habitación colectiva y aquellos considerados como focos de insalubridad resultaron compulsivas y en muchos casos brutales". CAPONI, "Miasmas", pp. 157 y 173. En México se llevaron a cabo inspecciones similares por parte de los higienistas y miembros del Consejo Superior de Salubridad. Al respecto, véase CARrILlo, "Del miedo", pp. 123-129. 121 "Carta enviada al C. Jefe del Departamento de Desinfección. 26 de enero de 1916.” AHSSA, Salubridad Pública. Epidemiología, c. 10, exp. 5, 1915-1916; "Relación de sustancias gastadas en el Departamento de Desinfección el 26 de noviembre de 1915”, AHSS, Salubridad Pública. 
Otro tema importante fue el aseo personal, pues ya se había identificado al piojo como vector del contagio. Para ello se nombraron bañistas y peluqueros, quienes estuvieron encomendados de bañar y rapar a las personas, principalmente a las de bajos recursos económicos. El Consejo Superior de Salubridad nombró una comisión para contratar baños y peluquerías en los ochos cuarteles de la ciudad:

De acuerdo con las últimas medidas adoptadas por este consejo para combatir la epidemia de tifo se ha nombrado una comisión compuesta por 2 médicos y 3 ingenieros para que contraten el arrendamiento de los establecimientos de baños y peluquerías necesarios en los 8 cuarteles de la ciudad y además, el número suficiente de peluqueros que todas las noches concurran a los dormitorios públicos y asilos, para cortar el pelo a los individuos que se alojan en ellos. ${ }^{122}$

Un mandamiento general de la campaña sanitaria concretizaba que el mejor medio para combatir la transmisión y propagación del tifo era instaurar la "guerra contra la suciedad",

Epidemiología, c. 10, exp. 2, 1915-1916; “Carta enviada al Consejo Superior de Salubridad y firmada el 18 de diciembre de 1915”, AHSSA, Salubridad Pública. Epidemiología, c. 10, exp. 2, 1915-1916.

${ }^{122}$ Los baños que operaron fueron: Baños del Niágara. $3^{\text {a }}$ del F. C. de Cintura; Paraíso, Cuadrante de Sta. Catarina; Baños de Peralvillo, Avenida Peralvillo; de Hidalgo, $3^{a}$ de Hidalgo; Santa María la Ribera, ubicado en el barrio del mismo nombre. "Oficio con sello del Consejo Superior de Salubridad firmado el 8 de febrero de 1916 y abajo del sello dice a máquina Servicio Especial Contra el tifo." "Oficio del Consejo Superior de Salubridad firmado por el presidente del Consejo el 13 de diciembre de 1915 y enviado al Secretario de Gobernación.” AHSSA, Salubridad Pública. Epidemiología, c. 6, exp. 10, 1915-1916. Véase también BELTRÁN Rabadán, "La epidemia”, pp. 175-176. 
la cual se dividía en tres rubros principales: el aseo personal, la limpieza de la habitación y la de los espacios públicos. Dentro de la primera se encontraban el aseo y el baño, por lo que se propuso que para beneficio público, el gobierno debía tener el control de la administración de los más importantes baños de la ciudad. También se ordenó declarar obligatorio el baño para todos los empleados del gobierno. Esta exigencia es importante y habla del carácter generalizado de la campaña en 1915, a diferencia del periodo anterior analizado por Carrillo, cuando sólo se ordenó el aseo forzoso a las clases pobres. Para el aseo de las habitaciones se crearon brigadas sanitarias con el fin de vigilar la higiene de los cuartos y ordenar la limpieza que se ameritara. En cuanto a los espacios públicos, se conminó a recolectar la basura, los desechos y el estiércol. Por último, se recomendaba utilizar antisépticos, para lo cual se sugería facilitar su introducción y comercio, como ocurrió con los productos de primera necesidad. ${ }^{123}$

Como se ha indicado, otros lugares que reportaron gran número de enfermos fueron los asilos, cárceles y cuarteles militares. De acuerdo con Orvañanos, en octubre de 1915 $50 \%$ de los enfermos de tifo eran militares o bien sus familiares. Los ejércitos, como los migrantes, fueron objeto de atención por parte de las autoridades sanitarias. La campaña fue dirigida hacia esos sectores y clases marginadas, pues eran los más proclives a contraer la enfermedad. ${ }^{124}$ En el interesante

123 "Carta del 22 de octubre de 1915 con rúbrica ilegible. No se indica a quién va dirigida ni qué personaje o dependencia la firma." AHSSA, Salubridad Pública. Epidemiología, c. 6, exp. 10, 1915-1916. Sobre las campañas de higiene y limpieza a los pobres y sus viviendas, véase Carrillo, "Del miedo", p. 117.

124 Ana María Carrillo muestra cómo desde el porfirismo el tifo fue identificado de manera creciente como la enfermedad de los cuarteles milita- 
libro de traslado de enfermos aparecen varios registros de los cuarteles ubicados en Donceles, en donde en ocasiones no se indica el nombre del enfermo, sino sólo se menciona que "se recogieron varios enfermos". Ante el gran número de contagios en estos lugares, el Consejo Superior de Salubridad giró una instrucción al jefe del Cuerpo Médico Militar para informarle de "los defectos que adolecen algunos cuarteles de la ciudad". Los médicos y funcionarios del organismo obtuvieron de la Secretaría de Guerra y Marina que dictara disposiciones para fomentar la higiene en los cuarteles y diversos lugares que ocupan los soldados "que guarnecen esta Plaza". Lo anterior mediante varias fajinas del tren de ambulancia, instrucción que se solicitaba se hiciera extensiva a los cuarteles ubicados en las municipalidades. El 20 de diciembre de 1915 la situación era tal que el presidente del Consejo Superior recomendaba que los cuarteles militares se instalaran en las afueras de la ciudad, dejando sólo la vigilancia de la policía en la ciudad. Estaba por arribar de Veracruz un contingente militar, llamado "Supremos Poderes", el cual aseguraban que no traía piojos y sus ropas estaban limpias, "pues cada soldado tiene suficientes trajes y buen calzado y cuidan personalmente de su higiene personal". ${ }^{125}$

\footnotetext{
res, los navíos, las prisiones, los asilos y los lazaretos, lugares en donde los individuos vivían hacinados, sin ventilación y con mala alimentación. Las campañas sanitarias se dirigieron a inspeccionar estos lugares. Por su parte, en Brasil y Argentina estrategias "como la desinfección de los espacios, el control de la vivienda popular y el control de inmigrantes se repitieron antes y después de la revolución pasteuriana". CARRILlo, "Del miedo", p. 116; Caponi, “Miasmas", p. 160.

125 "Acta de la sesión del 30 de octubre de 1915" y “Acta de la sesión extraordinaria del 20 de diciembre de 1915. AHSSA, Salubridad Pública. Presidencia, Actas de sesión.
} 
Domingo Orvañanos atribuyó el gran número de enfermos de tifo en los cuarteles militares a la suciedad, ya que por regla general los soldados no se esforzaban por su higiene ni por la de su dormitorio. Al respecto, ponía el ejemplo del cuartel de San Idelfonso, en donde desde la época de Huerta, los soldados levantaron las duelas del piso "para defecar ahí y no tener la molestia de salir la cuadra al excusado [sic]". Así, se podía imaginar que no había nada de "extraño que allí se hallan multiplicado los gérmenes del mal". Por lo anterior consideraba que si el porfiriato no había logrado cambios sustanciales en los hábitos de aseo personal, menos se alcanzaría en los años de la Revolución. La defecacion en las calles era frecuente, sobre todo en las proximidades de plazas y mercados. ${ }^{126}$ Pero también debemos considerar la alimentación, ya que seguramente los soldados no comían bien y vivían en condiciones infrahumanas.

En 1915 en los cuarteles militares no sólo la población masculina se contagió de tifo, sino también un importante grupo de mujeres. Por ejemplo, de los 126 enfermos de los cuarteles militares que fueron trasladados a los hospitales, 74 eran hombres y 52 mujeres. En agosto de 1915 se formó una cuadrilla de trabajadores para la limpieza y desinfección de los cuarteles debido a que constituían un serio peligro por sus deplorables condiciones de higiene, en particular el de Rodríguez Puebla y el de San Idelfonso, que con frecuencia fueron reportados en el registro de enfermos. ${ }^{127}$

126 “Acta de la sesión celebrada el día 20 de marzo de 1915.” AHSSA, Salubridad Pública. Presidencia, Actas de sesión; González Navarro, Población y sociedad, p. 148.

127 "Acta de la sesión 28 de agosto de 1915 y 4 de septiembre de 1915", AHSSA, Salubridad Pública. Presidencia, Actas de sesión. 
También en el libro del traslado de enfermos se registraron pacientes de tifo provenientes de los asilos constitucionalistas, ubicados en las calles Donceles, Puente de Alvarado, Plaza de la Merced y Chapultepec. Por ejemplo, en los asilos de Puente de Alvarado y de la calle Donceles, en un solo mes se denunciaron 37 enfermos de tifo y 10 enfermos de "la piel”, los cuales fueron trasladados al Hospital General. ${ }^{128}$ A fines de año, en "las Instrucciones Populares contra el tifo", publicadas por El Demócrata, apareció una nota sobre la situación de los asilos y albergues, cuya población había aumentado notablemente en los últimos tiempos debido a la guerra y la miseria, que desplazaron hacia la ciudad a un gran número de indigentes. $\mathrm{Al}$ respecto, se señalaba lo siguiente:

Los enfermos de tifo, siempre o casi siempre proceden de esos albergues humildísimos en los que se aglomeran gentes completamente desaseadas y viven en amigable contubernio con toda clase de insectos y cuyos dormitorios, si así pueden llamarse, nadie se cuida de ventilar ni de mantener siquiera en estado de mediana limpieza contribuyendo de este modo a perpetuar la enfermedad y olvidando por completo que la limpieza es la madre de la salud. ${ }^{129}$

El peligro que encarnaban este tipo de albergues era que los individuos enfermos "alojados en esos antros" abandonaran el lugar y diseminaran el contagio. Por tal motivo, se consideraba deber de las autoridades "perseguir con mano

\footnotetext{
128 "Relación que manifiesta la traslación de enfermos infecto-contagiosos a los hospitales. Noviembre de 1915”, AHSSA, Salubridad Pública. Epidemias, c. 11, exp. 1.

${ }^{129}$ El Demócrata (13 dic. 1915), p. 3.
} 
dura la vagancia y la mendicidad", pero para que la gente no abandonara esos lugares se debía dotar a estos lugares de todas las condiciones higiénicas necesarias para hacerles agradable su estancia, situación que no siempre se cumplió. ${ }^{130}$

Es interesante referir que a partir de enero de 1916, la campaña higienista empieza a difundirse de manera profusa y constante en la prensa nacional. Se atribuía la disminución de casos al éxito de la campaña encabezada por José María Rodríguez, quien incluso llegó a afirmar que el brote de 1915 no había sido una epidemia, sino una manifestación endémica del tifo. Sin embargo, como vimos antes, sí se trató de un brote epidémico, evidencia que se constata al comparar las cifras de enfermos y muertos con los años previos, así como el periodo de duración. No dejan de llamar la atención las alabanzas a la campaña higienista encabezada por el médico coahuilense. Por ejemplo, se informaba que por primera vez en 44 años decreció la enfermedad gracias a las medidas sanitarias promovidas por los esfuerzos del Consejo Superior de Salubridad. Según la nota, en enero de 1916 el número de enfermos había decrecido $60 \% .{ }^{131}$ Estas estimaciones

${ }^{130}$ El Demócrata (13 dic. 1915), p. 3. Desde fines del siglo XIx fue cada vez más frecuente equiparar la enfermedad con los pobres, sobre todo con sus viviendas y barrios. En 1892, durante una epidemia de tifo en Zacatecas, el Consejo Superior de Salubridad señaló como origen de la epidemia a la mendicidad y vagancia. Para enfrentar la epidemia se ordenó la reclusión de vagos y mendigos en lugares limpios y bajo la vigilancia de la policía. Carrillo, "Del miedo", pp. 116-117, 122.

${ }_{131} \mathrm{Al}$ respecto, se señalaba que en ese momento el promedio de casos era 80 por cada 10000 habitantes, cifra registrada al poniente, en el cuartel II. La prueba de que se trataba de una endemia era que tenía una estacionalidad previsible, pues en los meses de diciembre a abril de cada año se incrementaba el número de casos y éstos descendían hasta mayo. El Demócrata (30 ene. 1916), p. 1. 
no coinciden con la estadística del traslado de enfermos a los hospitales de la ciudad de México, pues en dicha fuente en ese solo mes la disminución fue de 552 casos, de 2132 a 1580.

En el segundo semestre de 1916 los estragos del tifo empezaron a decrecer. No obstante, la campaña sanitaria no decayó, sobre todo una vez que el gobierno constitucionalista empezó a afianzarse en el poder. En la prensa no cesaron de aparecer un sinnúmero de anuncios de jabones, remedios y medidas generales de higiene para prevenir el contagio de la enfermedad. Estaba claro que la mejor medida de prevención era la higiene personal, la limpieza y el barrido de calles, así como la desinfección de casas y lugares públicos. La disminución del número de casos se atribuía al éxito de la campaña sanitaria del presidente del Consejo Superior de Salubridad, José María Rodríguez, quien años más tarde afrontaría otro gran problema de salud pública: el impacto de la pandemia de influenza de 1918.

\section{REFLEXIONES FINALES}

La epidemia de tifo de 1915 y 1916 fue otro daño colateral de la guerra. Cuantificar y medir con exactitud cuál fue su magnitud es todavía una tarea pendiente, ya que las estadísticas disponibles abren una serie de interrogantes. Si bien se dispone de diversas publicaciones, estudios y de la prensa, no contamos con una serie continua de entierros, puesto que hay importantes vacíos de información, principalmente durante los años más cruentos de la guerra. De este modo, consideramos que existe un fuerte subregistro de decesos, principalmente en la ciudad de México. Lo que sí podemos asegurar es que la gravedad de la epidemia no 
puede explicarse sin considerar diversos factores: el progresivo deterioro en las condiciones de vida de la población y la interrupción de las campañas sanitarias, sobre todo a raíz de la crisis política desencadenada por el golpe militar de Huerta y de la lucha entre las distintas facciones revolucionarias. Las gráficas y los hallazgos demográficos del impacto del tifo de 1915 y 1916 incluidos en este artículo son una prueba más de las condiciones de pobreza y marginación de amplios sectores sociales. Si bien la capital del país no fue de las zonas más devastadas por la guerra y las enfermedades, sí podemos asegurar que la pauperización y deterioro en los servicios sanitarios afectó la salud de la población citadina. El estudio de estos primeros años de la guerra es un primer intento por reconstruir la estadística de enfermos y muertos. El patrón de mortalidad identificado hasta el momento revela una elevada mortandad infantil y adulta, lo que hace pensar en sus repercusiones a mediano y largo plazo.

En este texto también se muestra que la movilización de tropas fue una de las principales vías de diseminación del tifo en 1915 y 1916. Esta epidemia reveló la endeble actuación del gobierno para prevenir el brote del verano de 1915. Por su parte, la aparición del tifo muestra las deplorables condiciones de insalubridad y miseria de la capital del país en donde, a pesar de no haberse librado las grandes batallas militares, se vivió día con día el paso de la enfermedad y la muerte. Queda pendiente evaluar el éxito de la campaña sanitaria del gobierno constitucionalista y su impacto en la disminución de los casos de tifo a partir de marzo de 1916, cuyos logros fueron reiteradamente publicados en la información oficial publicada en la prensa. Empero, a simple vista podemos aventurar que la reclusión forzosa de enfermos, así como las medidas 
de higiene de lugares públicos, el baño obligatorio de individuos y prendas, evitaron de algún modo la diseminación masiva del contagio. Y, por otro lado, frenar la epidemia por medio de estas medidas de control social quizá ayudó a reforzar y a afianzar al recién triunfante gobierno constitucionalista.

\section{SIGLAS Y REFERENCIAS}

AHDF Archivo Histórico del Distrito Federal, México.

AHSSA Archivo Histórico de la Secretaría de Salubridad y Asistencia, México.

BJLB Biblioteca José Luis Bobadilla del Instituto Nacional de Salud Pública, México.

Agostoni, Claudia

"Los infinitamente pequeños: debates y conflictos en torno a la bacteriología (ciudad de México)", en Agostoni y SPeckMAN (eds.), 2005, pp. 167-192.

"Popular Health Education and Propaganda in times of Peace and War in Mexico City, 1890s-1920s", en American Journal of Public Health, 96: 1 (ene. 2006), pp. 52-61.

"Alfonso Pruneda", en Ludlow y Vázquez Semadeni (coords.), 2010, pp. 585-589.

Agostoni, Claudia y Andrés Ríos Molina

Las estadísticas de salud en México. Ideas, actores e instituciones, 1810-2010, con la colaboración de Gabriela Villarreal Levy, México, Universidad Nacional Autónoma de México, Secretaría de Salud, 2010.

Agostoni, Claudia y Elisa Speckman (eds.)

De normas y transgresiones. Enfermedad y crimen en América Latina (1850-1950), México, Universidad Nacional Autónoma de México, 2005. 
Arenzana, A. (ed.)

La población de México, vol. 4. México en el siglo XX, México, Consejo Nacional de Población, 1993.

Ávila Espinosa, Felipe Arturo

"La ciudad de México ante la ocupación de las fuerzas villistas y zapatistas. Diciembre de 1914-junio de 1915”, en MAtute y Sánchez Flores (eds.), pp. 1-17.

Betrán Moya, José Luis

Historia de las epidemias en España y sus colonias (1348-1919), Madrid, La Esfera de los Libros, 2006.

Beltrán Rabadán, María Eugenia

“La epidemia de tifo en la ciudad de México en 1915", tesis de licenciatura en historia, México, Universidad Nacional Autónoma de México, 2010.

“La epidemia de tifo en la ciudad de México en 1915”, en Molina del Villar, Márquez Morfín y Pardo Hernández (eds.), 2013, pp. 161-180.

Caponi, Sandra

"Miasmas, microbios y conventillos", en Asclepio, LIv: 1 (2002), pp. 155-182.

Carrillo, Ana María

"Surgimiento y desarrollo de la participación federal en los servicios de salud", en Fajardo, Carrillo y Neri, 2002, pp. 17-63.

“Estado de peste o estado de sitio? Sinaloa y Baja California, 1902-1903”, en Historia Mexicana, Liv: 4(216) (abr.-jun. 2005), pp. 1049-1103.

"Del miedo a la enfermedad al miedo a los pobres. La lucha contra el tifo en el México porfirista”, en Speckman, AgosTONi y GonZalbo (coords.), 2009, pp. 113-147. 
“Eduardo Liceaga”, en Ludlow y Vázquez Semadeni (coords.), pp. 371-375.

Cuenya, Miguel Ángel

Puebla de los Ángeles en tiempos de una peste colonial, México, El Colegio de Michoacán, Benemérita Universidad Autónoma de Puebla, 1999.

Revolución y tifo en la ciudad de Puebla, 1915-1916, México, Benemérita Universidad Autónoma de Puebla, 2008.

"Reflexiones en torno a la pandemia de influenza de 1918. El caso de la ciudad de Puebla”, en Desacatos, 32 (ene.-abr. 2010), pp. $145-158$.

Cuevas Cardona, Consuelo

"Ciencia de punta en el Instituto Bacteriológico Nacional (1905-1921)”, en Historia Mexicana, LVII: 1(225) (jul.-sep. 2007), pp. 53-89.

Estadísticas

Estadísticas sociales del porfiriato, 1877-1910, México, Talleres Gráficos de la Nación, 1956.

Fajardo, Guillermo, Ana María Carrillo y Rolando Neri

Pespectiva histórica de atención a la salud en México, 19022002, México, Organización Panamericana de la Salud, Universidad Nacional Autónoma de México, Sociedad Mexicana de Historia y Filosofía de la Medicina, 2002.

Florescano, Enrique y Elsa Malvido (comps.)

Ensayos sobre historia de las epidemias en México, I, México, Instituto Mexicano del Seguro Social, 1982.

Florescano, Enrique y Victoria San Vicente

Fuentes para la historia de la crisis agrícola (1809-1811). Selección documental, México, Universidad Nacional Autónoma de México, 1985. 
Foucault, Michel

El nacimiento de la clínica, México, Siglo Veintiuno Editores, 1979.

La vida de los hombres infames. Ensayos sobre desviación y dominación, Madrid, La Piqueta, 1990.

García Acosta, Virginia, Juan Manuel Pérez Zevallos y América Molina Del Villar

Desastres agrícolas en México. Catálogo bistórico. Épocas prehispánica y colonial (958-1822), México, Fondo de Cultura Económica, Centro de Investigaciones y Estudios Superiores en Antropología Social, Conaculta, 1999.

García García, Juan José

"Uso de algunos indicadores en epidemiología. Segunda parte”, en Revista Mexicana de Pediatría, 67:2 (mar.-abr. 2000), pp. 86-88.

Garciadiego, Javier

"La Revolución", en Nueva historia mínima de México, México, El Colegio de México, 2004, pp. 225-261.

González Navarro, Moisés

Población y sociedad en México (1900-1970), México, Universidad Nacional Autónoma de México, 1974, vol. 1.

Gortari Rabiela, Hira y Regina Hernández

Memorias y encuentros: la ciudad de México y el Distrito Federal (1824-1928), México, Departamento del Distrito Federal, Instituto de Investigaciones Dr. José María Luis Mora, 1988, vol. III.

Greer Gordon, Robert

“The Demographic Impact of the Mexican Revolution, 19101921”, tesis en Artes, Austin, Texas, University of Texas, 1966. 
Gudiño Cejudo, María Rosa

“Domingo Orvañanos", en Ludlow y Vázquez Semadeni (coords.), 2010, pp. 377-381.

“José María Rodríguez", en Ludlow y Vázquez Semadeni (coords.), 2010, pp. 559-563.

HARDEN, Victoria

“Typhus, Epidemic”, en Kiple (ed.), 1999, pp. 1080-1084.

“Typhus, Murine”, en Kiple (ed.), 1999, p. 1085.

Kiple, K. F. (ed.)

The Cambridge World History of Human Disease", Cambridge, Cambridge University, 1999.

KNight, Alan

La Revolución mexicana. Del porfiriato al nuevo régimen constitucional, vol. II, Contrarrevolución y reconstrucción, México, Grijalbo, 1986.

León, Nicolás

"¿Qué era el matlazahuatl y qué el cocoliztli en los tiempos precolombinos y en la época hispana”?, en Florescano y Malvido (comps.), 1982, pp. 383-397.

Livi Bacci, Massimo

"Las múltiples causas de la catásfrofe: consideraciones teóricas y empíricas”, en Revista de Indias, LXIII: 227 (2003), pp. 31-48.

Historia minima de la población mundial, Barcelona, Crítica Ariel, 2009.

Ludlow, Leonor y María Eugenia Vázquez Semadeni (coords.)

200 emprendedores mexicanos. La construcción de una nación, México, LID Editorial, 2010.

Marín Hernández, Juan José

"El control social y la disciplina histórica: un balance teó- 
rico metodológico", en Revista Historia de América, 1 (jul. 2001), pp. 1-4.

Márquez Morfín, Lourdes

La desigualdad ante la muerte en la ciudad de México. El tifo y el cólera, México, Siglo Veintiuno Editores, 1994.

Márquez Morfín, Lourdes y América Molina del Villar

"El otoño de 1918: las repercusiones de la pandemia de gripe en la ciudad de México", en Desacatos, 32 (2010), pp. 121-144.

Matute, Álvaro y Ricardo Sánchez Flores (eds.)

Estudios de historia moderna y contemporánea de México, vol. 14, documento 183, México, Universidad Nacional Autónoma de México, Instituto de Investigaciones Históricas, 1991, pp. 1-17. (Artículo disponible en http://www.historicas.unam.mx/moderna/ehcm14/183.html.)

Meyer, Jean

La Revolución mexicana, México, Tusquets editores, 2009.

Molina del Villar, América

La Nueva España y el Matlazabuatl, 1736-1739, México, Centro de Investigaciones y Estudios Superiores en Antropología Social, El Colegio de Michoacán, 2001.

"De la incertidumbre social y política a la enfermedad: el tifo, la viruela y la escarlatina en la ciudad de México, 1911-1914", en Molina del Villar, Márquez Morfín y Pardo HerNÁNDEZ (eds.), 2013, pp. 127-160.

Molina del Villar, América, Lourdes Márquez Morfín y Claudia Patricia Pardo Hernández (eds.)

El miedo a morir. Endemias, epidemias y pandemias en México. Análisis de larga duración, México, Centro de Investigaciones y Estudios Superiores en Antropología Social, Instituto de Investigaciones Dr. José María Luis Mora, Benemérita Universidad Autónoma de Puebla, Consejo Nacional de Ciencia y Tecnología, 2013. 
Ordorica, Manuel y José Luis Lezama

"Consecuencias demográficas de la Revolución mexicana”, en Arenzana (ed.), 1993, pp. 8-31.

Pani, Alberto

La higiene en México, México, Imprenta de J. Ballesca, 1916.

Pérez Moreda, Vicente

Las crisis de mortalidad en la España interior, siglos XVI Y XIX, Madrid, Siglo Veintiuno Editores, 1980.

Rodríguez Kuri, Ariel

Historia del desasosiego. La revolución en la cindad de México, 1911-1922, México, El Colegio de México, 2010.

Sánchez Uriarte, María del Carmen

"Entre la salud pública y la salvaguarda del reino. Las fiebres misteriosas de 1813 y la guerra de Independencia en la Intendencia de México", en Molina del Villar, Márquez Morfín y Pardo Hernández (eds.), 2013, pp. 51-74.

Speckman, Elisa, Claudia Agostoni y Pilar Gonzalbo (coords.)

Los miedos en la historia, México, El Colegio de México, Universidad Nacional Autónoma de México, 2009.

Tenorio Trillo, Mauricio

"De piojos, ratas y mexicanos", en ISTOR. Revista de Historia Internacional, xi: 41 (verano 2010), pp. 3-73.

UlloA, Berta

Historia de la Revolución Mexicana, vol. 6, La Constitución de 1917, México, El Colegio de México, 1983.

"La lucha armada (1911-19120)", en D. Cosío Villegas, Historia General de México, México, El Colegio de México, 2000, pp. 759-821. 
Valenzuela, Francisco

"Medidas profilácticas contra la propagación del tifo", en Memorias del Congreso Nacional del Tabardillo, México, Imprenta Francomexicana, 1919, pp. 263-271.

Vera Bolaños, Marta

"Ideas sobre la enfermedad e instituciones y medidas públicas de salud en México", México, El Colegio Mexiquense, 1999, pp. 1-25. 
